\title{
New Approaches to the Management of Adult Acute Lymphoblastic Leukemia
}

Renato Bassan, Jean-Pierre Bourquin, Daniel J. DeAngelo, and Sabina Chiaretti

Author affiliations and support information (if applicable) appear at the end of this article.

Published at jco.org on September 21, 2018.

Corresponding author: Renato Bassan, MD, Hematology Unit, Ospedale dell'Angelo, Via Paccagnella 11, 30174 Mestre, Venezia, Italy; e-mail: Renato. bassan@aulss3.veneto.it.

(C) 2018 by American Society of Clinical Oncology

0732-183X/18/3699-1/\$20.00
ASSOCIATED CONTENT

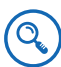

Appendix

DOI: https://doi.org/10.1200/JCO 2017.77.3648

DOI: https://doi.org/10.1200/JCO.2017. 77.3648

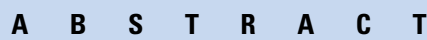

Traditional treatment regimens for adult acute lymphoblastic leukemia, including allogeneic hematopoietic cell transplantation, result in an overall survival of approximately $40 \%$, a figure hardly comparable with the extraordinary $80 \%$ to $90 \%$ cure rate currently reported in children. When translated to the adult setting, modern pediatric-type regimens improve the survival to approximately $60 \%$ in young adults. The addition of tyrosine kinase inhibitors for patients with Philadelphia chromosome-positive disease and the measurement of minimal residual disease to guide risk stratification and postremission approaches has led to additional improvements in outcomes. Relapsed disease and treatment toxicity—sparing no patient but representing a major concern especially in the elderly-are the most critical current issues awaiting further therapeutic advancement. Recently, there has been considerable progress in understanding the disease biology, specifically the Philadelphia-like signature, as well as other high-risk subgroups. In addition, there are several new agents that will undoubtedly contribute to additional improvement in the current outcomes. The most promising agents are monoclonal antibodies, immunomodulators, and chimeric antigen receptor T cells, and, to a lesser extent, several new drugs targeting key molecular pathways involved in leukemic cell growth and proliferation. This review examines the evidence supporting the increasing role of the new therapeutic tools and treatment options in different disease subgroups, including frontline and relapsed or refractory disease. It is now possible to define the best individual approach on the basis of the emerging concepts of precision medicine.

\section{J Clin Oncol 36. (9) 2018 by American Society of Clinical Oncology}

\section{INTRODUCTION}

In Western countries, new cases of adult acute lymphoblastic leukemia (ALL) occur at an annual rate of approximately one per 100,000, with a bimodal distribution decreasing at age 45 to 54 years and increasing again in people older than 55 years, totaling approximately 2,300 new cases per year for patients older than 15 years $(n=$ 1,750 between ages 15 and 55 years) in the United States. ${ }^{1,2}$ Over the past decade, we have witnessed an incredible therapeutic improvement. Currently, pediatric patients have an estimated 5-year overall survival (OS) approaching $90 \% .^{3-5}$ Modern pediatric programs thrive on an intensified use of corticosteroids (mainly dexamethasone), antimetabolites (especially methotrexate and 6-mercaptopurine) and L-asparaginase/ pegylated-asparaginase, and rely on minimal residual disease (MRD) analysis for additional dose intensification or allogeneic hematopoietic cell transplantation (HCT). ${ }^{6-8}$
RECENT ADVANCES USING PEDIATRIC REGIMENS IN ADULTS

The results in adult ALL, unfortunately, have not kept pace with those in pediatric ALL, with OS rates $<45 \%{ }^{9}$ despite the addition of CNS prophylaxis, late intensification with prolonged maintenance chemotherapy, and an extensive use of HCT in high-risk (HR) subsets. Currently, pediatric-inspired regimens are being administered in young adult patients, leading to improvements in event-free survival (EFS) and OS rates as compared with historical controls. ${ }^{10-13}$ This approach, initially reserved for adolescents and young adults (AYA; $<40$ years old) $)^{10,14,15}$ and later applied to patients up to 50 to 60 years of age, ${ }^{11,12,16}$ has increased the 5-year OS rate to $\geq 50 \%$, and up to $70 \%$ to $80 \%$ in favorable subsets (ie, AYA, standard risk, MRD negative; Appendix Table A1, online only), ${ }^{17}$ but not in older patients, whose survival decreases progressively to $<20 \%$. $^{2-4}$ Finally, allogeneic HCT is 


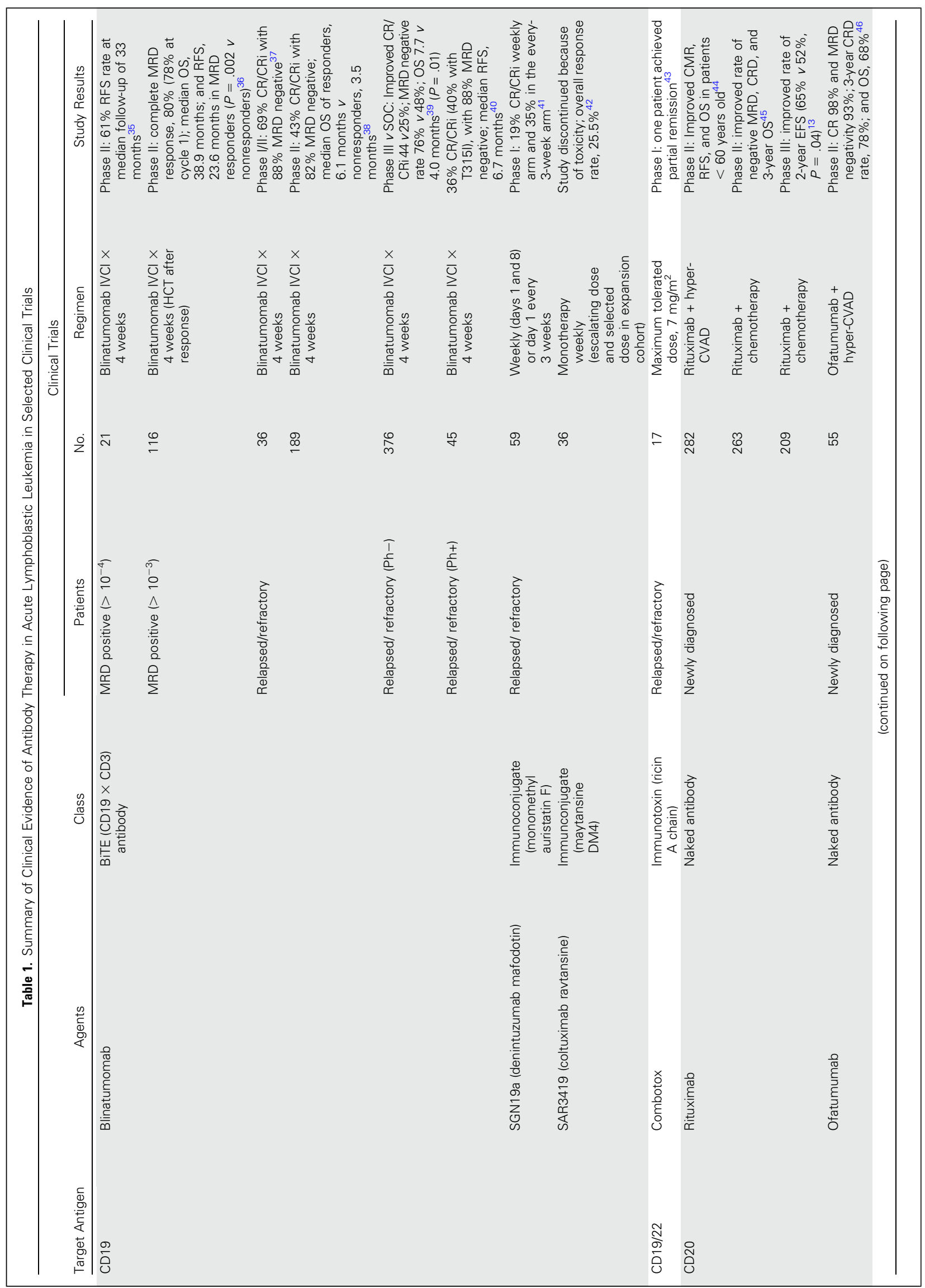




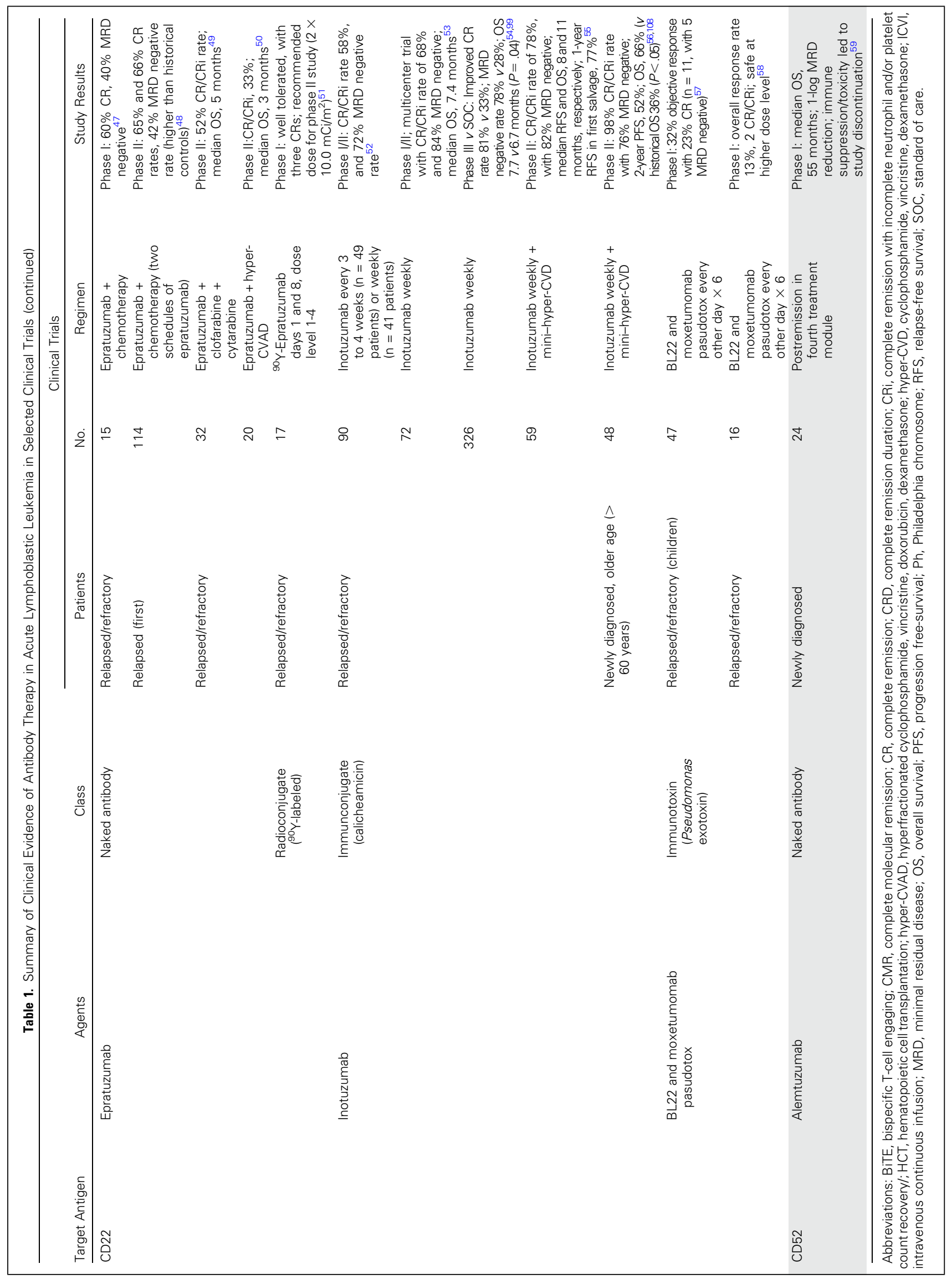




\begin{tabular}{|c|c|c|c|c|c|}
\hline Study & Phase, Status & Population & $\begin{array}{l}\text { Costimulatory } \\
\text { Domain }\end{array}$ & Efficacy & Toxicity \\
\hline $\begin{array}{l}\text { Kite Pharma } \\
\left(_{\text {(ZUMA-3) }}^{61}\right.\end{array}$ & Phase $1 / I I$ & $\begin{array}{l}\text { Adults }(n=11 ; \text { infused } \\
\quad n=10)\end{array}$ & CD28 & CR/CRi 75\%, all MRD negative & $\begin{array}{l}\text { Grade } 3+\text { CRS, } 20 \% \text {; grade } \\
\text { 3+ neurologic toxicity, } \\
40 \% \text {; one grade } 5 \mathrm{MOF}, \\
\text { CRS related (no cerebral } \\
\text { edema) }\end{array}$ \\
\hline $\begin{array}{l}\text { Kite Pharma } \\
\left(_{(Z \cup M A-4)^{62}}\right.\end{array}$ & Phase $1 / I I$, ongoing & $\begin{array}{l}\text { Pediatric and adolescents } \\
\qquad(n=5 ; \text { infused, } n=4)\end{array}$ & CD28 & $\begin{array}{l}\text { CR/CRi } 100 \% \text {, all MRD } \\
\text { negative }\end{array}$ & $\begin{array}{l}\text { No grade } 3+\text { CRS; one grade } \\
3 \text { neurologic event }\end{array}$ \\
\hline $\mathrm{MSKCC}^{63}$ & Phase I & $\begin{array}{c}\text { Adults }(\mathrm{n}=32 \mathrm{R} / \mathrm{R} ; \mathrm{n}=21 \\
\text { MRD }+ \text { [marrow blasts } \\
<0.01 \% \text { to }<5 \%] \text { ) }\end{array}$ & CD28 & $\begin{array}{l}\text { CR, 83\%; CMR } 67 \% \text {; median } \\
\text { EFS, } 6.1 \text { months (CMR } v \text { no } \\
\text { CMR patients: } 12.5 \text { months } v \\
3.1 \text { months; } P<.001 \text { ). } \\
\text { Median OS, } 12.9 \text { months } \\
\text { (CMR } v \text { no CMR patients: } \\
20.7 \text { months } v 6.6 \text { months; } \\
P<.001 \text { ) }\end{array}$ & $\begin{array}{l}26 \% \text { severe CRS (one related } \\
\text { death); grade } 3-4 \\
\text { neurotoxicity, } 42 \%\end{array}$ \\
\hline
\end{tabular}

often considered in first complete remission (CR) in adults with HR disease to reduce the risk of relapse, ${ }^{18}$ but potential benefits may be offset by transplant-related morbidity and mortality, especially in the elderly. ${ }^{19}$

\section{Risk Stratification}

Current risk stratification criteria reflect the clinical and prognostic heterogeneity of ALL and determine which patients should undergo more intensive treatment including HCT, due to the high risk of relapse. Besides patient-related characteristics, namely advanced age and poor performance status, recognized risk factors include hyperleukocytosis, early thymic-precursor (ETP) phenotype and adverse cytogenetics or genetics (ie, $\mathrm{t}(9 ; 22) / B C R$ $A B L 1$ rearrangement [Philadelphia chromosome positive $(\mathrm{Ph}+)$ ALL], Ph-like ALL, t $(4 ; 11) / K M T 2 A-A F F 1$ rearrangement, hypodiploidy, mutated TP53, and other abnormalities). ${ }^{20}$ In all studies, MRD has proven to be a major independent risk factor for relapse. ${ }^{21}$ In contrast to MRD-negative patients (typically defined as having $<10^{-4}$ residual leukemic cells in their CR marrow compared with baseline), MRD-positive patients are seldom cured with chemotherapy alone. In prospective trials performed over the past 25 years, enrolling $>1,500$ patients, ${ }^{22-24}$ OS was between $60 \%$ and $80 \%$ with chemotherapy alone in MRD-negative patients, even in HR subsets and Ph+ ALL. ${ }^{25}$ Instead MRD-positive patients benefit partially from HCT, although with OS rates $\leq 50 \%$ in intention-totreat analyses, due to the cumulative effects of pre- and posttransplantation relapse and transplant-related deaths. ${ }^{26-28}$

\section{Current Therapeutic Limitations}

The treatment of older patients represents a major obstacle, ${ }^{29}$ and, at all ages, relapse affects one-third or more of the patients and remains an unsolved issue due to extremely poor results with standard salvage chemotherapy. An international study of 1,706 patients with refractory or recurrent $(\mathrm{R} / \mathrm{R}) \mathrm{B}$-cell precursor $(\mathrm{BCP})$ ALL reported 3-year survival rates of only $10 \% .{ }^{30}$ Results are worse in $\mathrm{Ph}+\mathrm{ALL}^{31}$ and T-cell precursor (TCP) ALL, with some mitigation provided by nelarabine. ${ }^{32}$ Another concern is high-grade toxicity causing death in remission, which increases with age and with transplants ( $\geq 20 \%$ in most studies).

\section{The Challenge of New Management Options}

Despite these constraints, the management of adult ALL can be improved. This new era started with the advent of tyrosine kinase inhibitors (TKI) for Ph+ ALL, ${ }^{33}$ flourished with immunotherapy for BCP ALL and is now empowered by novel immunotherapeutics

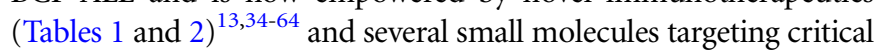
metabolic pathways (Fig 1; Tables 3 and 4), used alone or in combination in specific ALL subsets (Fig 2). More robust data on toxicity, dosing, and therapeutic implications are required and will be generated by ongoing trials (Appendix Tables A2-A7, online only); however, some of these agents could improve the cure rate and prompt a shift in the therapeutic regimens for ALL. The most promising agents currently available are those targeting cell membrane antigens (namely, CD19, CD20, and CD22) and major molecular pathways controlling cell proliferation and apoptotic response (ie, multiple kinases and members of Bcl-2, TP53, RAS, mTOR/PI3K, pre-B/B-cell receptor, and NOTCH networks). Furthermore, new molecular and drug profiling techniques might become essential to define targets and compounds deserving evaluation in trials or individual patients. This new strategy is still largely speculative, especially in frontline therapy, because molecular sequencing and new drug-sensitivity screening models have not yet been sufficiently tested or validated in early clinical trials. This review focuses on the rationale supporting this change and illustrates 
Type A targets (cell membrane):

B- and T-cell markers

Monoclonal antibodies and derivatives (eg, rituximab [CD20], inotuzumab ozogamicin [CD22], blinatumomab [CD19 x CD3])

Chimeric antigen receptor $\mathbf{T}$ cells and NK cells (eg, CD19, CD20,

CD22, CD5, CD7)

Checkpoint inhibitors (eg, nivolumab, pembrolizumab [PD1, PD-L1])

Type B targets (intracellular): Proliferation, apoptosis and cell differentiation pathways
Inhibitors

(eg, TKI, NOTCH1, BCL2/BCX, BCL6, JAK/STAT, HDAC, MYC, MTOR, PI3K

SYK, MEK, MDM2...) Agonists

(P53, SMAC-mimetics, ...) Differentiating agents (IL-3, M-/GM-CSF)

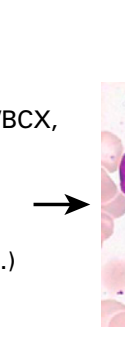

$\downarrow$

$\downarrow$

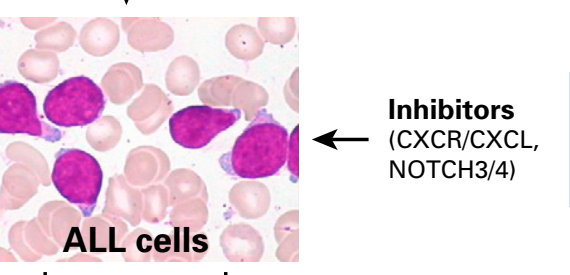
Type $\mathrm{C}$ targets
(marrow microenvironment):
Leukemia-sustaining
structures

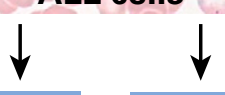

Molecular profiling

New drug profiling and PDX models

Identification of actionable targets (types A, B, C)

Drug sensitivity patterns $v$ ALL subsets

Drug associations

Fig 1. Actionable targets and drugs for innovative therapeutics in adult ALL. New therapeutic targets are membrane markers associated with B- or T-cell functions (type

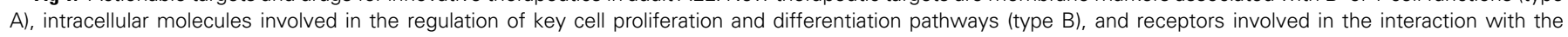

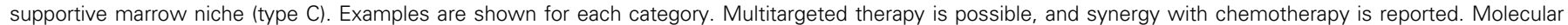

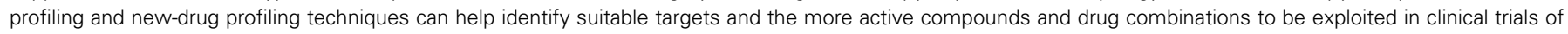
subset- and patient-specific therapy. ALL, acute lymphoblastic leukemia; NK, natural killer; PDX, patient-derived xenograft.

how new treatment approaches and related experimental work are likely to modify and improve the management of adult ALL.

\section{ACTIONABLE TARGET AND DRUG SCREENING}

\section{Molecular Profiling}

Although targets for immunotherapy can be identified by diagnostic immunophenotype, ALL subtype classification and target identification rely mostly on molecular genetics for the detection of gene rearrangements, translocations, and actionable recurrent mutations with genome-wide technologies. ${ }^{65-69}$ In the era of precision medicine, molecular profiling has gained in importance for the management of this disease. New concepts for targeted therapies and combinatory approaches with immunotherapy and/or chemotherapy require sophisticated experimental modeling and are now increasingly entering clinical development (Fig 2; Appendix Tables A2-A10).

\section{Drug Profiling Platforms}

Because the molecular classification of ALL is often insufficient to capture the complex biology of the disease and provide a predictive guide for treatment, ${ }^{70}$ functional screening approaches are being explored to generate drug response profiles directly from clinical samples, leading to proof-of-concept results and raising interest in exploring this approach in clinical trials (Fig 3). The first screening platform tested a customized library of kinase inhibitors, ${ }^{71}$ leading to a prospective trial in relapsed acute myeloid leukemia. The Primary Blood Cancer Encyclopedia project, which integrates short-term drug testing data with transcriptome and DNA methylome analysis, strongly supported the value of phenotypic screening in hemato-oncology. ${ }^{72}$ Some platforms are based on large viability assays for high-throughput testing ${ }^{72-74}$ with the advantage of simplicity and lower costs, and other, more sophisticated platforms are based on automated microscopy, which can discriminate leukemia cells with the normal microenvironment at the single-cell level. ${ }^{75,76}$ Functional screens of ALL samples maintained on mesenchymal stromal cells identified unexpected dependencies in defined HR ALL subtypes, ${ }^{77}$ captured response heterogeneity across ALL subtypes, efficiently discriminated patients on the basis of drug sensitivity ${ }^{75,78,79}$ and detected new pathways and vulnerabilities in resistant disease. ${ }^{75,77-80}$

\section{New Disease Models}

Drug development can be accelerated using humanized mouse models with primary leukemia ${ }^{81,82}$ that enable systematic preclinical drug testing. ${ }^{83,84}$ Patient-derived xenograft (PDX) biobanks integrate extensive genomic and clinical information, ${ }^{75,85-88}$ mirror the clonal architecture of leukemia initiating cells, ${ }^{89-92}$ maintain the genetic composition of the 
Table 3. Major BCP and TCP ALL Subsets of Interest for Molecular Targeted Therapy in Adult ALL: Subset Identification Through Cytogenetics/Genetics and GenomeWide Technologies

\begin{tabular}{|c|c|c|c|}
\hline ALL Subset & Prevalence; Prognosis & Main Aberration & Other Aberration \\
\hline \multicolumn{4}{|l|}{ BCP ALL } \\
\hline $\begin{array}{l}\text { BCR-ABL 1+/ t(9;22)(q34;q11.2) } \\
(\mathrm{Ph}+)\end{array}$ & $\begin{array}{l}20 \% \text { to approximately } 50 \% \text {, } \\
\text { increasing with age; unfavorable, } \\
\text { improved by TKI }\end{array}$ & $B C R-A B L 1$ rearrangement & $\begin{array}{l}\text { Deletions of IKZF1 and CDKN2AI } \\
B ; \text { ABL1 mutations } \\
\text { (recurrence/resistance) }\end{array}$ \\
\hline Ph-like & $\begin{array}{l}10 \%-15 \% \text { of childhood ALL, } 27 \% \\
\text { of AYA, } 20 \% \text { in adult ALL; } \\
\text { unfavorable }\end{array}$ & $\begin{array}{l}\text { Gene expression profile similar to } \\
B C R-A B L 1+A L L \text { except for lack } \\
\text { of } B C R-A B L 1 \text { rearrangement }\end{array}$ & $\begin{array}{l}\text { Deletions of IKZF1, TCF3, EBF1, } \\
\text { PAX5, and VPREB1; dic(9;20) } \\
\text { and IAMP21; CRLF2 } \\
\text { deregulated; JAK members } \\
\text { mutations; rearrangements } \\
\text { involving } A B L 1, J A K 2, C R L F 2, \\
\text { PDGFRB, EBF1 }\end{array}$ \\
\hline $\begin{array}{l}K M T 2 A-A F F 1+/ t(4 ; 11)(q 21 ; \\
\text { q23.3), KMT2A-rearranged/t(v; } \\
\text { 11q23.3) }\end{array}$ & $\begin{array}{l}\text { Approximately } 5 \%(M L L-K M T 2 A+) \text {; } \\
\text { unfavorable }\end{array}$ & $\begin{array}{l}\text { KMT2A-AFF1 or KMT2A-other } \\
\text { partner-gene rearrangement }\end{array}$ & $\begin{array}{l}\text { Few additional aberrations; } \\
\text { KRAS, NRAS, FLT3, NF1, } \\
\text { PTPN11, and PIK3R1 } \\
\text { mutations; epigenetic } \\
\text { regulatory gene mutations }\end{array}$ \\
\hline TCF3-PBX1+A (1;19)(q23;p13) & $\begin{array}{l}10 \%-15 \% \text {; relatively favorable } \\
\text { with intensive therapy }\end{array}$ & TCF3-PBX1 rearrangement & $\begin{array}{l}\text { Deletions of } P A X 5 \text { and } \\
C D K N 2 A / B\end{array}$ \\
\hline IAMP21 & Approximately $2 \%$; unfavorable & - & $\begin{array}{l}\text { Deletions of IKZF1, CDKN2A/B, } \\
\text { PAX5, ETV6, and } R B 1 ; \\
\text { chromosome X gain; } P 2 R Y 8- \\
\text { CRLF2 rearrangement }\end{array}$ \\
\hline $\begin{array}{l}\text { Hypodiploid, further classified as } \\
\text { near-haploid ( } 24-30 \\
\text { chromosomes) and low- } \\
\text { hypodiploid (31-39 } \\
\text { chromosomes) }\end{array}$ & $\begin{array}{l}\text { Children: } 0.5 \% \text { of both near-haploid } \\
\text { or low-hypodiploid, adults: low } \\
\text { hypodiploid } 3 \%-4 \% \text {; poor } \\
\text { prognosis }\end{array}$ & $\begin{array}{l}\text { TP53, RAS, PI3K, and IKZF } \\
\text { members }\end{array}$ & - \\
\hline$t(v ; 14 q 32)$ & $\begin{array}{l}<5 \% \text {, higher incidence in } \\
\text { adolescents; unfavorable }\end{array}$ & $\begin{array}{l}\text { IGH fusion with partner genes } \\
\text { CRLF2, ID4,CEBP, BCL2, EPOR, } \\
\text { LHX4, and IL-3 }\end{array}$ & CDKN2A deletions \\
\hline $\begin{array}{l}\text { Translocations/deletions/ } \\
\text { mutations in Xp22.3/Yp11.3 }\end{array}$ & $\begin{array}{l}\leq 7 \%,>50 \% \text { in Down syndrome } \\
\quad A L L, 50 \% \text { in } B C R-A B L \text {-like ALL; } \\
\text { unfavorable }\end{array}$ & $\begin{array}{l}C R L F 2-I G H, P 2 R Y \&-C R L F 2 \\
\text { rearrangements }\end{array}$ & $\begin{array}{l}\text { JAK1/2 mutations }(\leq 50 \%) \\
\text { IKZF1 deletions in } \mathrm{HR} \text { ALL }\end{array}$ \\
\hline 9p13 deletions/translocations & $\begin{array}{l}\text { Approximately } 25 \% \text {, possibly } \\
\text { involved in leukemogenesis; no } \\
\text { effect on outcome }\end{array}$ & $\begin{array}{l}\text { PAX5 fusion with partner genes } \\
\text { ETV6, ELN, POM121, PML, } \\
\text { FOXP1, MLLT3, JAK2, } \\
\text { C20orf112, AUTS2, CHFR, SOX5, } \\
\text { POM121C }\end{array}$ & - \\
\hline 7p12.2 focal deletions/mutations & $\begin{array}{l}40 \% \text { overall; } 15 \% \text { in childhood and } \\
50 \% \text { in adult ALL; unfavorable/ } \\
\text { controversial prognosis }\end{array}$ & Deletion of IKZFI & - \\
\hline \multicolumn{4}{|l|}{ TCP ALL } \\
\hline 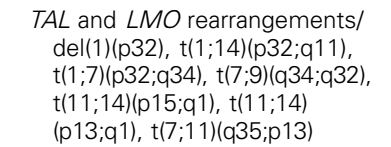 & $\begin{array}{l}30 \%-40 \% \text {; favorable, partly } \\
\text { depending on additional lesions }\end{array}$ & $\begin{array}{l}\text { SIL-TAL1 rearrangement, TCR } \\
\text { rearrangements with } T A L 1 \text {, } \\
T A L 2, L M O 1, \angle M O 2\end{array}$ & $\begin{array}{l}\text { PTEN mutations and deletions, } \\
\text { MYC rearrangements }\end{array}$ \\
\hline $\begin{array}{l}\text { HOXA aberrations/inv(7) } \\
\text { (p15q34), t(7;7)(p15;q34), } \\
\text { t(10;11)(p13;q14), t(v;11q23), } \\
\text { del(9)(q34), }\end{array}$ & $\begin{array}{c}\text { Approximately } 20 \%-25 \% \text {; outcome } \\
\text { depending on additional lesions }\end{array}$ & $\begin{array}{l}\text { TCR-HOXA rearrangement, } \\
M L L T 10 \text { and } M L L \\
\text { rearrangements with various } \\
\text { partners, SET-NUP214 } \\
\text { rearrangement }\end{array}$ & $I L 7 R$ and $J A K 1 / 3$ mutations \\
\hline $\begin{array}{l}\text { TLX3-5q35 rearrangement/ } \\
\text { t(5;14)(q35;q32) }\end{array}$ & $\begin{array}{l}20 \%-24 \% \text { childhood ALL, } 10 \% \\
\text { adult ALL }\end{array}$ & $T L X 3-B C L 11 B$ rearrangement & - \\
\hline $\begin{array}{l}\text { TLX1-10q24 rearrangements/ } \\
t(7 ; 10)(q 34 ; q 24), t(10 ; 14), \\
(q 24 ; q 11)\end{array}$ & $\begin{array}{l}3 \%-8 \% \text { childhood ALL, 20\%-30\% } \\
\text { adult ALL }\end{array}$ & TCR-TLX11 rearrangement & $\begin{array}{l}\text { PTPN2 mutations and deletions, } \\
\text { PHF6 mutations, NUP214- } \\
\text { ABL1 and EML1-ABL1 } \\
\text { rearrangements }\end{array}$ \\
\hline $\begin{array}{l}\text { NKX2-1/NKX2-2 rearrangements/ } \\
\text { inv(14)(q11.2q13), t(7;14) } \\
(q 34 ; q 13), \text { inv }(14)(q 13 q 32.33), \\
t(14 ; 20)(q 11 ; p 11)\end{array}$ & $6 \%$ & $\begin{array}{l}\text { TCR/IGH-NKX2- or NKX2-2 } \\
\text { rearrangements }\end{array}$ & - \\
\hline $\begin{array}{l}\text { LYL/MEF2C rearrangement } \\
\text { and immature cluster/t(7;19), } \\
(q 34 ; p 13), \text { del }(5)(q 14)\end{array}$ & $\begin{array}{l}\text { 3\%-17\%; unfavorable, survival } \\
\text { improved by intensive treatment }\end{array}$ & $\begin{array}{l}\text { TCR with } L Y L 1 \text { and } M E F 2 C \\
\text { rearrangements }\end{array}$ & $\begin{array}{l}\text { JAK1/3 mutations, IL7R, N-RAS, } \\
\text { FLT3, epigenetic modulators } \\
\text { (ie, IDH1/2, DNMT3A, EZH2, } \\
\text { EED, SUZ12, SETD2 and } \\
\text { EP300), transcription factors } \\
\text { (ie, RUNX1, ETV6, GATA3 and } \\
\text { IKZF1); RUNX1-AFF3, ETV6- } \\
\text { NCOA2, BCL11B- }\end{array}$ \\
\hline
\end{tabular}

NOTE. Dashes indicate no data.

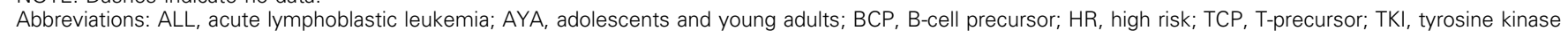
inhibitor. 


\begin{tabular}{|c|c|c|c|}
\hline ALL Subsets & Dysfunctional Gene Category & Molecular Targets & Targeting Agents \\
\hline $\begin{array}{l}\text { TCP: NUP214-ABL1+, EML1- } \\
\quad A B L 1+\end{array}$ & Kinase aberrations & $\begin{array}{l}\text { BCR-ABL1, PDGFRB, MERTK, } \\
\quad \text { ICK, TNK2 }\end{array}$ & TKI \\
\hline Various (BCP and TCP) & JAK/STAT deregulation & $\begin{array}{l}\text { JAK1/2, CRLF2, IL7R, PTPRC, } \\
\text { PTPN2 }\end{array}$ & $\begin{array}{l}\text { JAK inhibitors, mTOR } \\
\text { inhibitors }\end{array}$ \\
\hline $\begin{array}{l}\text { KMT2A-rearranged, } \\
\text { hyperdiploid and hypodiploid, } \\
\text { FLT3-mutated TCP }\end{array}$ & $R A S$ signaling deregulation & $F L T 3, N / K-R A S$ & $\begin{array}{l}\text { FLT3 inhibitors, mTOR } \\
\text { inhibitors, PI3K/mTOR } \\
\text { dual inhibitors, allosteric } \\
\text { MEK1/2 inhibitor }\end{array}$ \\
\hline KMT2A-rearranged & Epigenetic deregulation & CREBBP, SETD2, DOT1L & $\begin{array}{l}\text { DOT1L inhibitors, histone } \\
\text { deacetylase inhibitors }\end{array}$ \\
\hline $\begin{array}{c}\text { MLL-rearranged, } \\
\text { TCF3-HLF+ }\end{array}$ & Apoptosis deregulation & $B C L 2$ & Bcl-2 inhibitors \\
\hline
\end{tabular}

Abbreviations: ALL, acute lymphoblastic leukemia; BCP, B-cell precursor; TCP, T-cell precursor; TKI, tyrosine kinase inhibitor.

xenografted sample, ${ }^{75,77,89,93}$ and enable testing of new agents on samples from clinically representative cohorts of patients, providing survival cues and a longer window for combinatorial drug testing. Impressive results have been reported from a first trial assessing drug sensitivity in patients with refractory hematologic malignancies, using multiparametric image-based immunocytometry to distinguish the effect of drugs on malignant and normal blood cells. ${ }^{76}$ Of 48 patients, informative results could be used for 17 who received assay-guided treatment, including two patients with BCP ALL, resulting in responses in eight patients (one with ALL). These results will stimulate the design of larger clinical studies on specific disease entities to capture the full potential

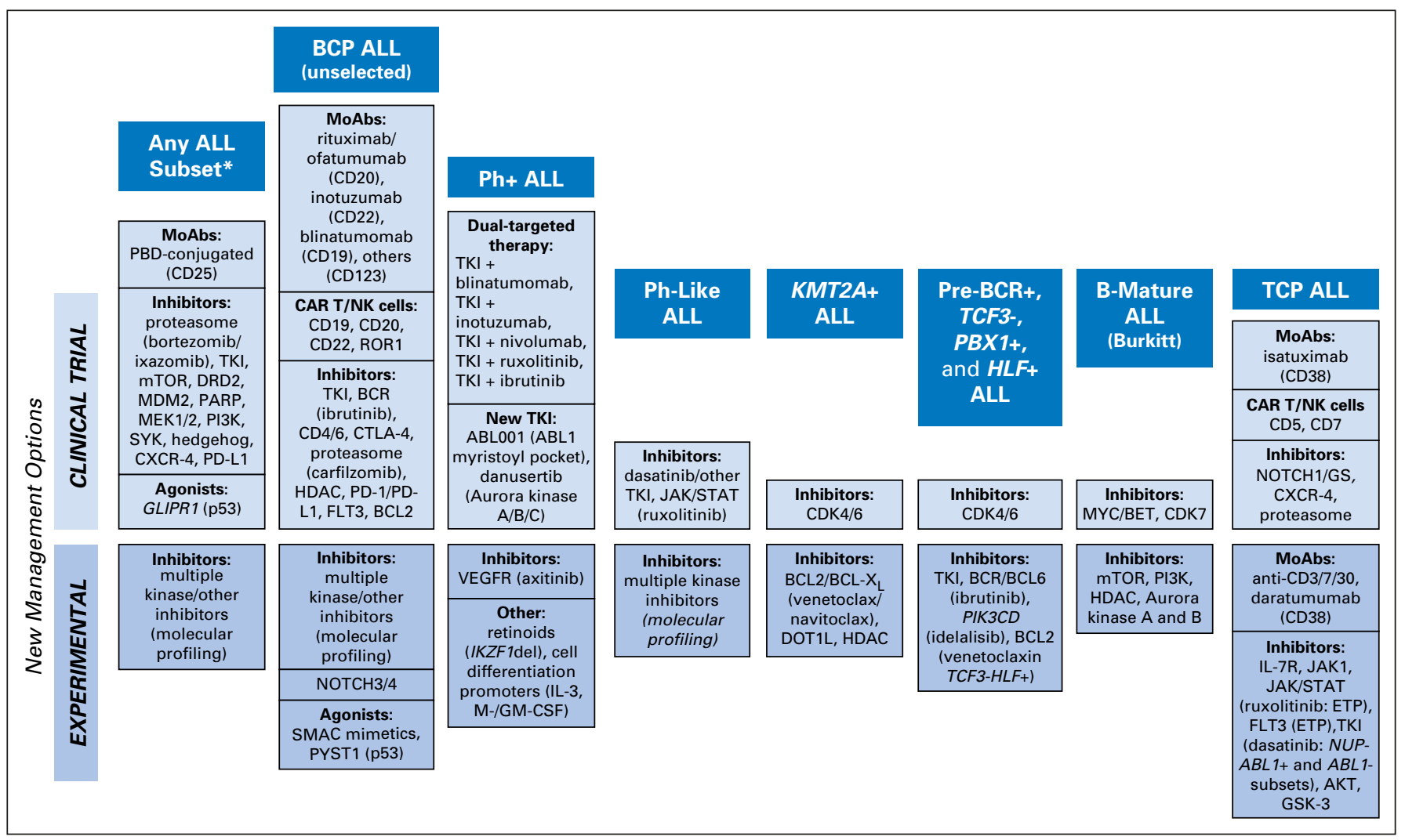

Fig 2. Subset-specific approaches with new therapeutics in adult ALL. Clinical and preclinical experimental approaches with new management options for adult ALL and subsets. Clinical trial evidence extracted from ClinicalTrials.gov repository, accessed April 2017. ALL, acute lymphoblastic leukemia; CAR, chimeric antigen receptor; BCP, B-cell precursor; MoAb, monoclonal antibody; NK, natural killer; PBD, pyrrolobenzodiazepine; TCP, T-cell precursor; TKI, tyrosine kinase inhibitor. $\left({ }^{*}\right)$ By trial eligibility 


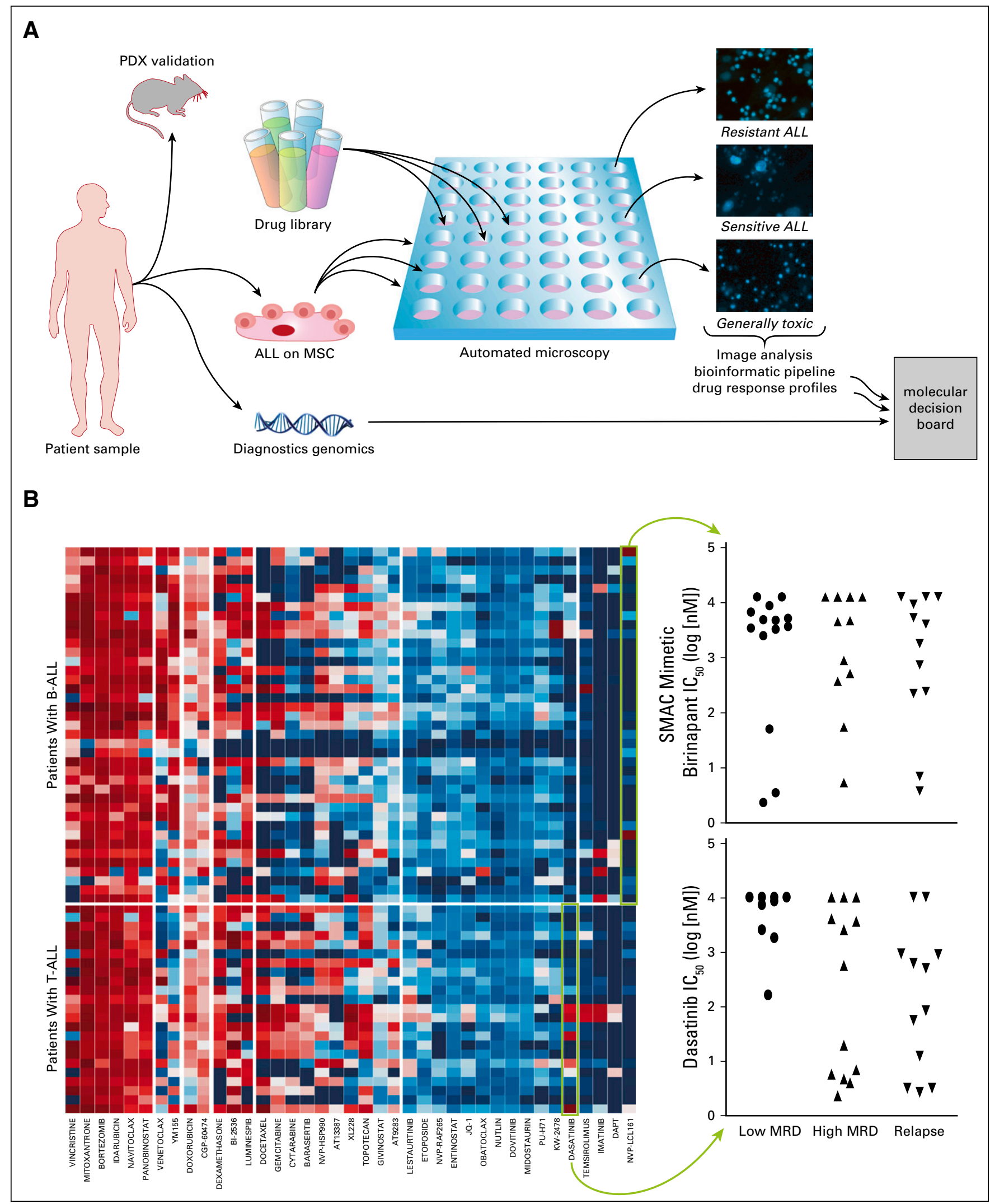

Fig 3. Drug response profiling of primary patient samples. (A) Workflow for phenotypic screens of cocultures of primary ALL cells on human MSCs using large-scale automated microscopy. Generation of PDXs provides a renewable source of representative ALL cells for mechanistic research but may also be invaluable for deeper coclinical validation experiments depending on the clinical situation. (B) Example of drug response profiling output. $I_{50}$ values on the basis of (continued on next page) 
of drug response profiling with the aims of avoiding unnecessary toxicity of inappropriate salvage regimens and improving responses in selected subgroups.

\section{Functional Drug Screening for Molecularly Unclustered $A L L$}

The usefulness of functional drug screening is being explored in patients with ALL not included in specific molecular clusters. For example BCL2-dependent ALL was identified by screening PDX models for sensitivity to $\mathrm{BH} 3$ mimetics, including venetoclax, ${ }^{75,77,85,94,95}$ and drug combinations established to overcome resistance. ${ }^{75,96}$ Similarly, selective sensitivity to alternative RIP-1-dependent cell-death pathways (eg, necroptosis by SMAC [second mitochondrial-derived activator of caspases] mimetics) not exploited by current antileukemic agents were discovered. ${ }^{80,97}$ PDX models have also been used to elucidate the critical dependence on altered metabolic function. ${ }^{98-100}$ This underscores the importance of cross-referencing drug responses over many samples in a structured database to establish the effective and expected dose-response range for relevant outliers (ie, drug-sensitivity patterns not predicted by the molecular ALL subset).

\section{NEW MANAGEMENT OPTIONS WITH IMMUNOTHERAPEUTICS}

\section{Rituximab}

In BCP ALL, the expression of CD20 confers a poor prognosis. ${ }^{101}$ Rituximab, a chimeric anti-CD20 antibody, was evaluated in combination with chemotherapy for untreated patients with $\mathrm{Ph}-\mathrm{CD} 20+\mathrm{BCP}$ ALL. At the MD Anderson Cancer Center (MDACC), rituximab was added to the first four courses of the hyper-CVAD (cyclophosphamide, vincristine, doxorubicin) regimen. ${ }^{44}$ The results demonstrated an improved CR duration, a lower relapse rate, and an improved OS, but only in patients younger than 60 years as compared with historical controls $(70 \% v$ $38 \%, P<.001$; and $75 \% v 47 \%, P=.003)$. Comparable data were produced by the German adult ALL Study Group. ${ }^{45}$ The FrenchBelgian-Swiss Group for Research on Adult ALL evaluated the addition of rituximab in a phase III study using a pediatric-inspired regimen ${ }^{13}$ : Patients 18 to 59 years old received 16 to 18 rituximab doses, resulting in improved 2-year EFS from 52\% to 65\% ( $P=$ $.004)$ due to a decreased relapse rate with no increase in toxicity.

\section{Blinatumomab}

New antibody constructs have shown promise for R/R ALL. ${ }^{102}$ Blinatumomab, a bispecific T-cell engager construct, received US Food and Drug Administration and European Medicines Agency approval. Blinatumomab simultaneously targets CD19 (present on most BCP ALL cells) and CD3 (present on cytotoxic T cells) and acts to bring ALL cells into proximity of T cells, which are capable of tumor eradication. In a phase II study, ${ }^{38} 189$ adult patients with $\mathrm{Ph}-\mathrm{R} / \mathrm{R}$ BCP ALL received blinatumomab with $43 \%(\mathrm{n}=81$ of 189 ) of them achieving CR or CR with defective hematologic recovery, and $40 \%$ of responders able to successful transition to allogeneic HCT Importantly, 60 of 73 evaluable patients with CR (82\%) achieved MRD negativity. Results were similar in the phase III trial, with a $44 \%$ CR or CR with defective hematologic recovery rate in the blinatumomab arm compared with $25 \%$ in patients receiving chemotherapy, ${ }^{39}$ and a $76 \%$ rate compared with $48 \%$ in patients whose disease turned MRD negative. Although generally well tolerated, grade 3 or higher cytokine release syndrome (CRS) and neurologic toxicity was seen in $4.9 \%$ and $9.4 \%$ of patients, respectively. Blinatumomab was tested as a single agent in patients with $\mathrm{R} / \mathrm{R} \mathrm{Ph}+\mathrm{ALL}$; it induced a CR rate of $36 \%$ associated with $88 \%$ MRD-negative status ${ }^{40}$ and, in $\mathrm{Ph}-\mathrm{MRD}$-positive ALL, achieved an excellent response rate of $78 \%$, with prolonged survival, occasionally without HCT. ${ }^{36,103}$ Resistance mechanisms include a defective T-memory or regulator-cell response, PD1/PD-L1 overexpression, ${ }^{104}$ and emergence of CD19-negative subclones. $^{105}$

\section{Inotuzumab Ozogamicin}

Inotuzumab ozogamicin (INO) is an anti-CD22 antibody conjugated to calicheamicin; it is in late clinical development. A phase I/II study demonstrated a CR/ incomplete hematologic recovery rate of $68 \%$, with $84 \%$ of responding patients achieving MRD negativity. ${ }^{53}$ In a recent phase III trial, INO was superior to salvage chemotherapy for R/R ALL. Among the first 218 patients randomly assigned to treatment arm, $81 \%$ of those assigned to INO achieved CR, compared with $29 \%$ who received the standard of care, with a higher percentage of MRD-negative cases (78\% $v 28 \%$; $P<.001) .{ }^{54}$ Duration of remission and OS favored INO, as confirmed by a long-term update reporting a 2-year rate of $22.8 \%$ versus $10 \%$ in standard-care group $(P .001) .{ }^{106}$ However, hepatotoxicity was more frequent in the INO group (51\% $v 34 \%)$, including incidence of sinusoidal obstruction syndrome (13\% $v<1 \%$ ). Although most of the cases occurred after HCT, sinusoidal obstruction syndrome developed in five patients $(3 \%)$ receiving INO therapy alone. ${ }^{107}$ Given the proven efficacy of this compound on these studies, INO is being combined with chemotherapy in the frontline setting. Using a mini-hyper-CVD (cyclophosphamide, vincristine, dexamethasone) regimen with INO in elderly patients, 47 of 48 evaluable patients $(98 \%)$ achieved a CR/incomplete hematologic recovery $(\mathrm{n}=35 \mathrm{CR})$, coupled with flow-cytometric MRD-negative status in 76\%. Two-year progression-free survival and OS were $52 \%$ and $66 \%$, respectively. ${ }^{56,108}$

\section{Chimeric Antigen Receptor T Cells}

Cellular immunotherapy with CD19-directed chimeric antigen receptor (CAR) $\mathrm{T}$ cells represents another promising approach for R/R disease. Anti-CD19 CAR T cells have been the most

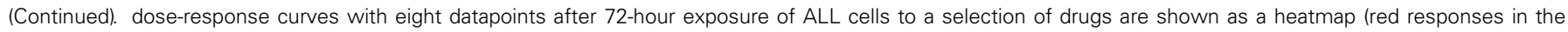

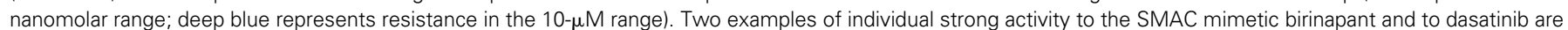

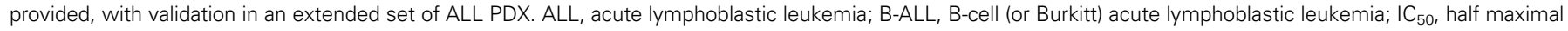

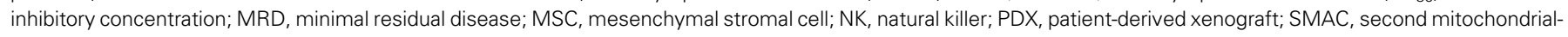
derived activator of caspases; T-ALL, T-cell acute lymphoblastic leukemia. 
extensively studied in trials using second-generation receptors, which comprise three components: an extracellular antigenrecognition domain derived from the single-chain variable fragment of a monoclonal antibody, an intracellular signaling domain (the $\mathrm{CD} 3 \mathrm{z}$ chain from the $\mathrm{T}$-cell receptor), and a costimulatory domain (most commonly, 4-1BB or CD28). ${ }^{109-111}$ Initial phase I/II studies using the CTL019 construct reported a 90\% CR rate in 30 patients ( $\mathrm{n}=25$ children, $\mathrm{n}=5$ adults). ${ }^{110}$ In addition, $88 \%$ of the patients who achieved a CR were MRD negative. Responses were durable, with seven relapses and 19 ongoing remissions (2 to 24 months) and with 15 patients receiving no additional therapy. High rates of CAR T-cell persistence (68\%) and associated B-cell aplasia was reported at 6 months. In collaboration with Novartis, CTL019 was administered to 75 children and young adults, with $81 \%$ achieving $\mathrm{CR}$ and concurrent MRD-negative status. At a median follow-up of 10.6 months, 29 remained in CR. One-year EFS and OS were $50 \%$ and $76 \%$, respectively. ${ }^{60}$ This led to the approval of tisagenlecleucel (Kymriah; Novartis, Basel, Switzerland), the first CAR product in the United States.

The outcomes in adult patients treated with CAR T cells has been less impressive, with median EFS and OS of 6.1 months and 12.9 months, respectively. ${ }^{63}$ CAR T cells but not natural killer cells ${ }^{112}$ could also be effective against CNS leukemia. ${ }^{113}$ Although anti-CD19 CAR T cells can generate rapid and impressive responses, therapy is associated with a unique set of severe adverse effects. The two major toxicities include CRS and neurotoxicity. In the CTL019 study, all patients experienced signs and symptoms of CRS, with eight of 30 patients requiring transfer to the intensive care unit. ${ }^{110}$ Fortunately, tocilizumab, an anti-IL6 receptor antibody, was found effective and has become the mainstay of management for severe CRS, because it is well tolerated and rapidly effective in most cases. Current approaches include optimization of the CAR T-cell product in defined proportions of CD4 and CD8 T-cell subsets, development of humanized CARs, CARs with two costimulatory domains, allogeneic CARs, and CARs against other antigens such as CD22.

\section{NEW MANAGEMENT OPTIONS IN MOLECULARLY DEFINED} ALL SUBSETS

\section{$P h+A L L$}

Outcome of $\mathrm{Ph}+\mathrm{ALL}$ was dramatically improved by TKIs. ${ }^{114-118}$ Single-agent imatinib or dasatinib plus corticosteroids therapy, pioneered by the Gruppo Italiano Malattie Ematologiche dell'Adulto $^{114,119}$ induced CR virtually in all patients without risk of induction death. With TKI-chemotherapy combinations, CR rate exceeded $95 \%$ but death occurred in $2 \%$ to $7 \%$ of the cases. In a randomized trial from the French-Belgian-Swiss Group for Research on Adult ALL, ${ }^{116}$ a combination of de-escalated chemotherapy plus TKI resulted in less induction toxicity and noninferior $\mathrm{CR}$ and survival results compared with standard chemotherapy plus TKI. In a MDACC study, ponatinib combined with hyper-CVAD led to an excellent $83 \%$ 2-year OS, even without HCT. ${ }^{115}$ In elderly and/ or frail patients (median age, 68 years; range, 27 to 85 years), ponatinib monotherapy resulted in $87.5 \% 1$-year OS, associated with a $45 \%$ molecular response rate in a Gruppo Italiano Malattie Ematologiche dell'Adulto study. ${ }^{120}$ Postremission consolidation is still based on intensive chemotherapy (plus TKI) and HCT, when feasible. This "global" strategy led to survival rates approaching 50\%, thus meaning we still need to improve.

Chemotherapy-free trials with TKI-immunotherapy combinations (eg, TKI-blinatumomab) are ongoing (Clinicaltrial.gov identifier: NCT02744768) and will clarify the place of this antibody construct especially in eradicating MRD. As for other ALL subsets, MRD persistence is associated with recurrence, whereas its negativity may identify patients with favorable prognosis in whom the indication for HCT could be reconsidered to spare morbidity and mortality. ${ }^{25}$ With these premises, relapse remains relatively frequent and is often sustained by mutations, the most deleterious being T315I. New, potentially active agents include axitinib, ${ }^{73}$ a vascular endothelial growth factor receptor inhibitor active in T315I-mutant disease; a new TKI, danusertib ${ }^{121}$; and ABL001 (asciminib), ${ }^{122}$ a novel allosteric TKI that binds to the myristoyl pocket of ABL1, causing an inactive kinase conformation (Clinicaltrial.gov identifier: NCT02081378, a phase I trial for patients intolerant/ refractory to standard TKI). Notably, a drug-sensitivity testing platform $^{123}$ allowed the identification of axitinib as a selective inhibitor of the T315I mutation. ${ }^{73}$

As for combinatory studies, of interest is the simultaneous administration of dasatinib, ruxolitinib, and dexamethasone, which research in vitro was shown to restore cytokine dependency, inhibit STAT3 and STAT5 activation, and prevent leukemia initiating cell growth and acquisition of mutations (Clinicaltrial.gov identifier: NCT02494882), ${ }^{124}$ and the combination of ruxolitinib with nilotinib (Clinicaltrial.gov identifier: NCT01914484). In cases with IKZF1 impairment, retinoids can induce $I K Z F 1$ re-expression, stimulate cell maturation. and restore in vitro TKI sensitivity. ${ }^{125}$ Moreover, promoters of myelomonocytic differentiation can successfully induce $\mathrm{Ph}+\mathrm{ALL}$ cells into nonleukemic monocytes/macrophages. ${ }^{126}$

\section{Ph-Like ALL}

The Ph-like subgroup, initially identified by gene expression profiling, accounts for approximately $20 \%$ of adult BCP ALL cases, with a prevalence in AYA. These cases are characterized by a transcriptional profile similar to that of $\mathrm{Ph}+$ ALL but lacking the $\mathrm{t}(9 ; 22) / B C R-A B L 1$ rearrangement. ${ }^{127-130}$ Instead, the underlying genomic lesions are heterogeneous, making its recognition difficult and uneven among trials. CRLF2 rearrangements are detected in approximately 50\%; lesions affecting ABL class genes (ie, $A B L 1, A B L 2, C S F 1 R, P D G F R A, P D G F R B)$ in approximately $10 \%$; and JAK/STAT genes (ie, JAK1-3, IL7R, and CRLF2 mutations) in $<10 \%$. Rearrangements in other TKs and the EPOR gene are extremely rare. IKZF1 deletions occur in $\leq 80 \%$ of cases. Patients with $\mathrm{Ph}$-like ALL have a poorer outcome when compared with other BCP ALL subsets and it is not yet clear whether they should receive an HCT up front, on the basis of MRD persistence only. ${ }^{128,131}$ Given the activated kinome profile, several groups are testing the combination of TKIs with chemotherapy. Children's Oncology Group is testing ruxolitinib in patients with CRLF2 rearrangements and/or JAK-STAT deregulation (Clinicaltrial.gov identifier: NCT02723994) or dasatinib in untreated patients (Clinicaltrial.gov identifier: NCT02883049), while MDACC is testing these drugs in pretreated patients (Clinicaltrial.gov identifier: NCT02420717) with disappointing results. ${ }^{132}$ Other experimental 
approaches use a variety of inhibitors on the basis of the individual molecular profile. The pan-TKI ponatinib could be effective regardless of the underlying genetic lesion. ${ }^{133}$

\section{MLL-Rearranged ALL}

The prognosis of $\mathrm{t}(4 ; 11) / K M T 2 A-A F F 1+$ and other $M L L$ rearranged ALLs is poor and could be improved by new targeted approaches. MLL (ie, KMT2A) rearrangements are associated with high levels of H3K79 methylation catalyzed by the DOTL1 enzyme. Therefore, DOT1L inhibitors, particularly EPZ-5676 (pinometostat), have been tested in R/R cases (Clinicaltrial.gov identifiers: NCT02141828 and NCT01684150) in both pediatric and adult cohorts. ${ }^{134}$ Furthermore, $M L L$-rearranged cases express high levels of Bcl-2, BAX, and BIM, but relatively low levels of BCL-XL and MCL-1, a mechanism directly sustained by KMT2A rearrangement on BCL2 expression and partly mediated by interaction with $\mathrm{H} 3 \mathrm{~K} 79 \mathrm{me} 2 / 3$. As a consequence, in vitro and xenograft model studies showed that the $\mathrm{Bcl}-2$ inhibitor venetoclax induces cell killing in synergy with chemotherapy. ${ }^{85,135,136}$ In addition, histone deacetylase inhibitors (HDACis) can exert synergistic activity with cytarabine by repressing cytidine deaminase. ${ }^{137}$

\section{TCF3-Rearranged ALL}

TCF3-PBX1+ ALL associated with $\mathrm{t}(1 ; 19)$ represents approximately one-half of the cases of the newly recognized pre-Bcell receptor $(\mathrm{BCR})+$ subset and is characterized by a favorable outcome with intensive treatment. These cases could be targeted by dasatinib because they overexpress many $\mathrm{TKs},{ }^{138}$ including the BCR-dependent TK ROR $1^{139}$ and Mer TK, which correlates with risk of CNS progression, ${ }^{140}$ by idelasib due to the high levels of $P I K 3 C D^{141}$ and ibrutinib via downmodulation of the pre-BCR signaling on BCL6. ${ }^{98,142,143}$

Instead, TCF3-HLF+ ALL is a very HR subset associated with $t(17 ; 19)$, often with high levels of BCL2 expression recalling venetoclax as a potential therapeutic compound. ${ }^{77}$ Drug response profiling predicted robust resistance to conventional drugs and confirmed a unique sensitivity to venetoclax. Combination therapy with dexamethasone, vincristine, and venetoclax in PDX from two patients maintained CR for up to 1 year. $^{77}$

\section{Hypodiploid BCP ALL}

Hypodiploid ALL is a rare, poor prognostic subtype including near-haploid (24 to 31 chromosomes), low hypodiploid (32 to 39 chromosomes), and high hypodiploid (40 to 43 chromosomes) ALL. ${ }^{144}$ RAS and PI3K pathways are frequently altered in nearhaploid ALL, whereas TP53 and IKZF members are often mutated in low hypodiploid ALL, pinpointing functional targeting using $\mathrm{PI} 3 \mathrm{~K}$ and PI3K/mTOR inhibitors. ${ }^{144,145}$ Germline mutational screening of TP53 should always be performed in these cases.

\section{Other BCP ALL Subsets}

Many other actionable deletions or mutations are emerging in BCP ALL (and sometimes TCP ALL). ${ }^{127,144,146-148}$ These involve pathways affecting lymphoid development, cell cycle, regulation of transcription, lymphoid and RAS signaling, epigenetic modifications, cytokine receptors, TK expression, and the JAK/STAT phosphorylation system (Tables 3 and 4). Focus is now on downstream members of the RAS pathway, namely the MEK and PI3K inhibitor BEZ235 (Clinicaltrial.gov identifier: NCT01756118), the allosteric MEK1/2 inhibitor selumetinib, trametinib, steroids, and FLT3 inhibitors (ie, lestaurtinib, midostaurin, and quizartinib, all being evaluated in phase I-II and III trials, respectively; Clinicaltrial. gov identifiers: NCT 00866281, NCT00557193, and NCT01411267). Among epigenetic regulators, the HDACis vorinostat and panobinostat are being investigated in phase I-II trials for $\mathrm{R} / \mathrm{R}$ disease (Clinicaltrial.gov identifiers: NCT01483690, NCT01321346, and NCT01321346); however, there have been reports of toxicity. ${ }^{148 a}$ JAK2 inhibitors (ruxotilinb) and Bcl-2 inhibitors might be used in cases harboring target mutations. SMAC mimetics, directly acting on apoptosis and necroptosis pathways, proteasome inhibitors, and checkpoint inhibitors, have shown in vitro activity and are being studied (Supplemental Data). The role of inhibitors of molecules involved in interaction with the marrow niche (ie, NOTCH3 and NOTCH4) is still largely undetermined ${ }^{149}$; targeting SCD and SPP1 genes and proteins ${ }^{150}$ and vascular endothelial growth factor A (with bevacizumab) could be useful against CNS leukemia. $^{151}$

\section{B-ALL (mature B/Burkitt leukemia)}

$M Y C$ rearrangements are the hallmark of B-ALL, leading to escape from cell-cycle control and a high proliferative rate. Thus, inhibition of $M Y C$-related pathways is an attractive option for refractory disease. MYC inhibitors JQ1 and THZ1 target MYC/ MAX heterodimerization and CDK7 (THZ1), whereas dependency of MYC activation on multiple enhancers and so-called superenhancers, such as a BET proteins and PI3K, are targeted by mTOR or HDACis, Aurora kinase A and B, and other BET inhibitors (namely, I-BET 151, GSK525762, and CPI-0610). ${ }^{152}$ New phase I trials are underway.

\section{TCP ALL}

TCP ALL accounts for approximately $25 \%$ of ALL cases and is further classified according to maturation stage (ie, early-, cortical-, and mature $\mathrm{T}$ ). With modern pediatric-based regimens adopting MRD or risk-oriented intensification, outcome of TCP ALL may be excellent and superior to that of BCP ALL. Among actionable molecular lesions, ${ }^{153}$ the most frequent is NOTCH1 mutation. NOTCH1 and the strictly associated $\gamma$-secretase inhibitors were tested in late-stage disease, with some responses of short duration and considerable gut toxicity. ${ }^{154}$ The best study reported one $\mathrm{CR}$ and an overall $32 \%$ response rate in 25 patients with relapsed disease. ${ }^{155}$ Theoretically, targeting NOTCH1-related overexpression of chemokine receptor CCR7 and its ligand CCL19 could reduce the risk of CNS disease. ${ }^{156}$ Many other targeting agents are being investigated, often in combination, like $\gamma$-secretase inhibitors and AKT inhibitors to revert glucocorticoid resistance $^{157-159}$ (Fig 2; Tables 3 and 4). Moreover, induction of T-cell receptor signaling led to apoptosis mimicking thymic negative selection, ${ }^{160}$ and targeting contact structures with the marrow microenvironment (ie, CXCR4, CXCL12) reduces proliferation and the propagation potential of leukemic stem cells. ${ }^{161,162}$ Notably, PDX and drug screening models identified a subset of refractory T-ALL responsive to dasatinib in a nanomolar range, 
correlating with strong responses in vivo after resistance to multiple other treatments. ${ }^{75}$

\section{ETP ALL}

This peculiar diagnostic subset (with weak or absent CD5 expression and mixed T-lympho/myeloid phenotype and genotype) is associated with poor outcome unless treated with very intensive MRD-based chemotherapy or HCT in first CR. ${ }^{163}$ ETP ALL is characterized by abnormalities typically observed in myeloid disorders, including mutations in RUNX1, ETV6, GATA3, IDH1, IDH2, DNMT3A, ${ }^{164,165}$ and the JAK/STAT pathway. In an experimental PDX model, ETP ALL was exquisitely sensitive to ruxolitinib, which abrogated IL-7-induced STAT5 phosphorylation. ${ }^{166}$ Furthermore, FLT3 inhibitors might be considered, because mutations are detected in approximately $35 \%$ of cases. ${ }^{167}$

\section{FUTURE DIRECTIONS}

We are entering an intensive phase of clinical investigations with new agents. To take advantage of these new treatment options, we will have to gradually shift from R/R ALL to the frontline setting, where treatment resistance is less likely to occur. ${ }^{168}$ We will certainly need to develop solutions to integrate functional and genomic data for reference bioinformatics tools supporting clinical decisions, in accordance with studies in patients with cancer including acute myeloid leukemia and childhood ALL. ${ }^{169-171}$ For the exploration of individualized or subset-specific treatment forms, it will be crucial to design prospective clinical studies with modular elements to evaluate optimal strategies for chemotherapy, ${ }^{172}$ immunotherapy, and combinations of molecularly targeted drugs and synergistic drug pairs, ${ }^{74,173}$ and detect activity in the early clinical trials more rapidly to pilot subsequent therapeutic developments.

\section{AUTHORS' DISCLOSURES OF POTENTIAL CONFLICTS OF INTEREST}

Disclosures provided by the authors are available with this article at jco.org.

\section{AUTHOR CONTRIBUTIONS}

Conception and design: All authors

Collection and assembly of data: All authors

Data analysis and interpretation: All authors

Manuscript writing: All authors

Final approval of manuscript: All authors

Accountable for all aspects of the work: All authors

\section{REFERENCES}

1. Sant $M$, Allemani $C$, Tereanu $C$, et al: Incidence of hematologic malignancies in Europe by morphologic subtype: Results of the HAEMACARE project. Blood 116:3724-3734, 2010

2. Howlander N., Noone A.M., Krapcho M., et al: SEER Cancer Statistics Review (CSR), 1975-2014. https://seer.cancer.gov/archive/csr/1975_2014/

3. Pulte $\mathrm{D}$, Gondos $\mathrm{A}$, Brenner $\mathrm{H}$ : Improvement in survival in younger patients with acute lymphoblastic leukemia from the 1980s to the early $21 \mathrm{st}$ century. Blood 113:1408-1411, 2009

4. Dores GM, Devesa SS, Curtis RE, et al: Acute leukemia incidence and patient survival among children and adults in the United States, 2001-2007. Blood 119:34-43, 2012

5. Pui $\mathrm{CH}$, Evans WE: A 50-year journey to cure childhood acute lymphoblastic leukemia. Semin Hematol 50:185-196, 2013

6. Pui $\mathrm{CH}$, Campana $\mathrm{D}$, Pei $\mathrm{D}$, et al: Treating childhood acute lymphoblastic leukemia without cranial irradiation. N Engl J Med 360:2730-2741, 2009

7. Wood $B L$, Winter SS, Dunsmore $K P$, et al: T-lymphoblastic leukemia (T-ALL) shows excellent outcome, lack of significance of the early thymic precursor (ETP) immunophenotype, and validation of the prognostic value of end-induction minimal residual disease (MRD) in Children's Oncology Group (COG) Study AALL0434. Blood 124:1, 2014

8. Larsen EC, Devidas M, Chen S, et al: Dexamethasone and high-dose methotrexate improve outcome for children and young adults with high-risk B-acute lymphoblastic leukemia: A report from Children's Oncology Group Study AALL0232. J Clin Oncol 34:2380-2388, 2016
9. Bassan R, Hoelzer D: Modern therapy of acute lymphoblastic leukemia. J Clin Oncol 29:532-543, 2011

10. Stock W, La M, Sanford B, et al: What determines the outcomes for adolescents and young adults with acute lymphoblastic leukemia treated on cooperative group protocols? A comparison of Children's Cancer Group and Cancer and Leukemia Group B studies. Blood 112:1646-1654, 2008

11. Huguet $F$, Leguay $T$, Raffoux $E$, et al: Pediatricinspired therapy in adults with Philadelphia chromosome-negative acute lymphoblastic leukemia: The GRAALL-2003 study. J Clin Oncol 27: 911-918, 2009 [Erratum: J Clin Oncol 2009;27(15): 2574]

12. DeAngelo DJ, Stevenson KE, Dahlberg SE, et al: Long-term outcome of a pediatric-inspired regimen used for adults aged 18-50 years with newly diagnosed acute lymphoblastic leukemia. Leukemia 29:526-534, 2015

13. Maury S, Chevret $S$, Thomas $X$, et al: Rituximab in B-lineage adult acute lymphoblastic leukemia. N Engl J Med 375:1044-1053, 2016

14. Ribera JM, Oriol A, Sanz MA, et al: Comparison of the results of the treatment of adolescents and young adults with standard-risk acute lymphoblastic leukemia with the Programa Español de Tratamiento en Hematología pediatric-based protocol ALL-96. J Clin Oncol 26:1843-1849, 2008

15. Boissel N, Auclerc MF, Lhéritier $V$, et al: Should adolescents with acute lymphoblastic leukemia be treated as old children or young adults? Comparison of the French FRALLE-93 and LALA-94 trials. J Clin Oncol 21:774-780, 2003

16. Storring JM, Minden MD, Kao S, et al: Treatment of adults with BCR-ABL negative acute lymphoblastic leukaemia with a modified paediatric regimen. Br J Haematol 146:76-85, 2009
17. Curran E, Stock W: How I treat acute lymphoblastic leukemia in older adolescents and young adults. Blood 125:3702-3710, 2015 [Erratum: Blood 2015;126(15):1868]

18. Goldstone $A H$, Richards $S M$, Lazarus $H M$, et al: In adults with standard-risk acute lymphoblastic leukemia, the greatest benefit is achieved from a matched sibling allogeneic transplantation in first complete remission, and an autologous transplantation is less effective than conventional consolidation/ maintenance chemotherapy in all patients: Final results of the International ALL Trial (MRC UKALL XII/ ECOG E2993). Blood 111:1827-1833, 2008

19. Gupta V, Richards S, Rowe J: Allogeneic, but not autologous, hematopoietic cell transplantation improves survival only among younger adults with acute lymphoblastic leukemia in first remission: An individual patient data meta-analysis. Blood 121: 339-350, 2013

20. Hoelzer D, Bassan R, Dombret $\mathrm{H}$, et al: Acute lymphoblastic leukaemia in adult patients: ESMO Clinical Practice Guidelines for diagnosis, treatment and follow-up. Ann Oncol 27(suppl 5):v69-v82, 2016

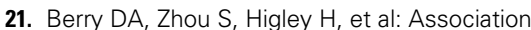
of minimal residual disease with clinical outcome in pediatric and adult acute lymphoblastic leukemia: A meta-analysis. JAMA Oncol 3:e170580, 2017

22. Brüggemann $M$, Raff $T$, Kneba $M$ : Has MRD monitoring superseded other prognostic factors in adult ALL? Blood 120:4470-4481, 2012

23. van Dongen JJ, van der Velden VH, Brüggemann $M$, et al: Minimal residual disease diagnostics in acute lymphoblastic leukemia: Need for sensitive, fast, and standardized technologies. Blood 125: 3996-4009, 2015

24. Bassan R, Spinelli O: Minimal residual disease monitoring in adult ALL to determine therapy. Curr Hematol Malig Rep 10:86-95, 2015 
25. Short NJ, Jabbour E, Sasaki K, et al: Impact of complete molecular response on survival in patients with Philadelphia chromosome-positive acute lymphoblastic leukemia. Blood 128:504-507, 2016

26. Gökbuget $N$, Kneba $M$, Raff $T$, et al: Adult patients with acute lymphoblastic leukemia and molecular failure display a poor prognosis and are candidates for stem cell transplantation and targeted therapies. Blood 120:1868-1876, 2012

27. Bassan R, Spinelli O, Oldani E, et al: Different molecular levels of post-induction minimal residual disease may predict hematopoietic stem cell transplantation outcome in adult Philadelphia-negative acute lymphoblastic leukemia. Blood Cancer J 4: e225, 2014

28. Dhédin N, Huynh A, Maury S, et al: Role of allogeneic stem cell transplantation in adult patients with Ph-negative acute lymphoblastic leukemia. Blood 125:2486-2496, quiz 2586, 2015

29. Gökbuget N: How I treat older patients with ALL. Blood 122:1366-1375, 2013

30. Gökbuget N, Dombret $H$, Ribera JM, et al: International reference analysis of outcomes in adults with B-precursor Ph-negative relapsed/refractory acute lymphoblastic leukemia. Haematologica 101: 1524-1533, 2016

31. Cortes JE, Kantarjian $\mathrm{H}$, Shah NP, et al: Ponatinib in refractory Philadelphia chromosomepositive leukemias. N Engl J Med 367:2075-2088, 2012

32. DeAngelo DJ, Yu D, Johnson JL, et al: Nelarabine induces complete remissions in adults with relapsed or refractory T-lineage acute lymphoblastic leukemia or lymphoblastic lymphoma: Cancer and Leukemia Group B study 19801. Blood 109: 5136-5142, 2007

33. Maino $E$, Sancetta $R$, Viero $P$, et al: Current and future management of $\mathrm{Ph} / \mathrm{BCR}-\mathrm{ABL}$ positive $\mathrm{ALL}$. Expert Rev Anticancer Ther 14:723-740, 2014

34. Maino E, Bonifacio M, Scattolin AM, et al: Immunotherapy approaches to treat adult acute lymphoblastic leukemia. Expert Rev Hematol 9: 563-577, 2016

35. Topp MS, Gökbuget N, Zugmaier G, et al: Long-term follow-up of hematologic relapse-free survival in a phase 2 study of blinatumomab in patients with MRD in B-lineage ALL. Blood 120: 5185-5187, 2012

36. Gökbuget $N$, Dombret $H$, Bonifacio $M$, et al: Blinatumomab for minimal residual disease in adults with B-cell precursor acute lymphoblastic leukemia. Blood 131:1522-1531, 2018

37. Topp MS, Gökbuget N, Zugmaier G, et al: Phase II trial of the anti-CD19 bispecific $T$ cellengager blinatumomab shows hematologic and molecular remissions in patients with relapsed or refractory B-precursor acute lymphoblastic leukemia. $\mathrm{J}$ Clin Oncol 32:4134-4140, 2014

38. Topp MS, Gökbuget N, Stein AS, et al: Safety and activity of blinatumomab for adult patients with relapsed or refractory B-precursor acute lymphoblastic leukaemia: A multicentre, single-arm, phase 2 study. Lancet Oncol 16:57-66, 2015

39. Kantarjian H, Stein A, Gökbuget N, et al: Blinatumomab versus chemotherapy for advanced acute lymphoblastic leukemia. N Engl J Med 376: 836-847, 2017

40. Martinelli G, Boissel N, Chevallier $P$, et al: Complete hematologic and molecular response in adult patients with relapsed/refractory Philadelphia chromosome-positive B-precursor acute lymphoblastic leukemia following treatment with blinatumomab:
Results from a phase II, single-arm, multicenter study. J Clin Oncol 35:1795-1802, 2017

41. Fathi AT, Borate U, DeAngelo DJ, et al: A phase 1 study of denintuzumab mafodotin (SGNCD19A) in adults with relapsed or refractory B-lineage acute leukemia (B-ALL) and highly aggressive lymphoma. Blood 126:1328, 2015

42. Kantarjian HM, Lioure B, Kim SK, et al: A phase II study of coltuximab ravtansine (SAR3419) monotherapy in patients with relapsed or refractory acute lymphoblastic leukemia. Clin Lymphoma Myeloma Leuk 16:139-145, 2016

43. Schindler J, Gajavelli S, Ravandi F, et al: A phase I study of a combination of anti-CD19 and antiCD22 immunotoxins (Combotox) in adult patients with refractory B-lineage acute lymphoblastic leukaemia. Br J Haematol 154:471-476, 2011

44. Thomas DA, O'Brien S, Faderl $S$, et al: Chemoimmunotherapy with a modified hyper-CVAD and rituximab regimen improves outcome in de novo Philadelphia chromosome-negative precursor Blineage acute lymphoblastic leukemia. J Clin Oncol 28:3880-3889, 2010

45. Hoelzer D, Huettmann A, Kaul F, et al: Immunochemotherapy with rituximab improves molecular CR rate and outcome in CD20+ B-lineage standard and high risk patients; results of $263 \mathrm{CD} 20+$ patients studied prospectively in GMALL Study 07/ 2003. Blood 116:170, 2010

46. Sasaki K, Kantarjian HM, Ravandi F, et al: Frontline ofatumumab in combination with hyperCVAD for adult patients with CD-20 positive acute lymphoblastic leukemia (ALL): Interim result of a phase II clinical trial. Blood 128:2783, 2016

47. Raetz EA, Cairo MS, Borowitz MJ, et al: Chemoimmunotherapy reinduction with epratuzumab in children with acute lymphoblastic leukemia in marrow relapse: A Children's Oncology Group Pilot Study. J Clin Oncol 26:3756-3762, 2008

48. Raetz EA, Cairo MS, Borowitz MJ, et al: Reinduction chemoimmunotherapy with epratuzumab in relapsed acute lymphoblastic leukemia (ALL) in children, adolescents and young adults: Results from Children's Oncology Group (COG) Study ADVL04P2. Blood 118:573, 2011

49. Advani AS, McDonough S, Coutre $S$, et al: SWOG S0910: A phase 2 trial of clofarabine/ cytarabine/epratuzumab for relapsed/refractory acute lymphocytic leukaemia. Br J Haematol 165:504-509, 2014

50. Chevallier $P$, Chantepie $S$, Huguet $F$, et al: Hyper-CVAD + epratuzumab as a salvage regimen for younger patients with relapsed/refractory CD22positive precursor B-cell acute lymphocytic leukemia. Haematologica 102:e184-e186, 2017

51. Chevallier $P$, Eugene T, Robillard N, et al: (90)Ylabelled anti-CD22 epratuzumab tetraxetan in adults with refractory or relapsed CD22-positive B-cell acute lymphoblastic leukaemia: A phase 1 dose-escalation study. Lancet Haematol 2:e108-e117, 2015

52. Kantarjian $H$, Thomas $D$, Jorgensen J, et al: Results of inotuzumab ozogamicin, a CD22 monoclonal antibody, in refractory and relapsed acute lymphocytic leukemia. Cancer 119:2728-2736, 2013

53. DeAngelo DJ, Stock W, Stein AS, et al: Inotuzumab ozogamicin in adults with relapsed or refractory CD22-positive acute lymphoblastic leukemia: A phase 1/2 study. Blood Adv 1:1167-1180, 2017

54. Kantarjian HM, DeAngelo DJ, Stelljes M, et al: Inotuzumab ozogamicin versus standard therapy for acute lymphoblastic leukemia. N Engl J Med 375: 740-753, 2016
55. Jabbour E, Ravandi F, Kebriaei $P$, et al: Salvage chemoimmunotherapy with inotuzumab ozogamicin combined with mini-hyper-CVD for patients with relapsed or refractory Philadelphia chromosomenegative acute lymphoblastic leukemia: A phase 2 clinical trial. JAMA Oncol 4:230-234, 2018

56. Sasaki K, Jabbour EJ, O'Brien SM, et al: Inotuzumab ozogamicin in combination with lowintensity chemotherapy (mini-hyper-CVD) as frontline therapy for older patients with acute lymphoblastic leukemia (ALL): Interim result of a phase II clinical trial. Blood 128:588, 2016

57. Wayne AS, Shah NN, Bhojwani D, et al: Phase 1 study of the anti-CD22 immunotoxin moxetumomab pasudotox for childhood acute lymphoblastic leukemia. Blood 130:1620-1627, 2017

58. Short NJ, Kantarjian $H$, Jabbour E, et al: A phase I study of moxetumomab pasudotox in adults with relapsed or refractory B-cell acute lymphoblastic leukaemia. Br J Haematol doi: 10.1111/bjh.14806 [epub ahead of print on June 14, 2017]

59. Stock W, Sanford B, Lozanski G, et al: Alemtuzumab can be incorporated into front-line therapy of adult acute lymphoblastic leukemia (ALL): Final phase I results of a Cancer and Leukemia Group B study (CALGB 10102). Blood 114:838, 2009

60. Maude SL, Laetsch TW, Buechner J, et al: Tisagenlecleucel in children and young adults with B-cell lymphoblastic leukemia. N Engl J Med 378: 439-448, 2018

61. Shah B, Wierda W-G, Schiller GJ, et al: KTEC19 chimeric antigen receptor (CAR) T cell therapy in adults with high-burden relapsed/refractory acute lymphoblastic leukemia (R/R ALL): Updated results from phase 1/2 of ZUMA-3. Haematologica 102:200, 2017 (suppl 2; abstr P523)

62. Lee DW Wayne AS, Huynh V, et al: Updated results from ZUMA-4: A phase 1/2 study of KTE-C19 chimeric antigen receptor (CAR) $T$ cell therapy in pediatric and adolescent patients with relapsed/ refractory acute lymphoblastic leukemia. Haematologica 102:346-347 (suppl 2; abstr E840), 2017

63. Park JH, Rivière I, Gonen $M$, et al: Long-term follow-up of CD19 CAR therapy in acute lymphoblastic leukemia. N Engl J Med 378:449-459, 2018

64. DeAngelo DJ, Ghobadi A, Park JH, et al: Clinical outcomes for the phase 2, single-arm, multicenter trial of JCAR015 in adult B-ALL (ROCKET Study). J Immunother Cancer 5:305-306, 2017 (suppl 2)

65. Chiaretti S, Li X, Gentleman R, et al: Gene expression profiles of B-lineage adult acute lymphocytic leukemia reveal genetic patterns that identify lineage derivation and distinct mechanisms of transformation. Clin Cancer Res 11:7209-7219, 2005

66. Mullighan CG: The molecular genetic makeup of acute lymphoblastic leukemia. Hematology (Am Soc Hematol Educ Program) 2012:389-396, 2012

67. Moorman AV: The clinical relevance of chromosomal and genomic abnormalities in B-cell precursor acute lymphoblastic leukaemia. Blood Rev 26: 123-135, 2012

68. Inaba H, Greaves M, Mullighan CG: Acute lymphoblastic leukaemia. Lancet 381:1943-1955, 2013

69. Hunger SP, Mullighan CG: Acute lymphoblastic leukemia in children. $\mathrm{N}$ Engl J Med 373: 1541-1552, 2015

70. Friedman AA, Letai $A$, Fisher DE, et al: Precision medicine for cancer with next-generation functional diagnostics. Nat Rev Cancer 15:747-756, 2015 
71. Tyner JW, Yang WF, Bankhead A III, et al: Kinase pathway dependence in primary human leukemias determined by rapid inhibitor screening. Cancer Res 73:285-296, 2013

72. Dietrich S, Oleś M, Lu J, et al: Drugperturbation-based stratification of blood cancer. J Clin Invest 128:427-445, 2018

73. Pemovska $T$, Johnson $E$, Kontro $M$, et al: Axitinib effectively inhibits BCR-ABL1(T315I) with a distinct binding conformation. Nature 519:102-105, 2015

74. Kurtz SE, Eide CA, Kaempf A, et al: Molecularly targeted drug combinations demonstrate selective effectiveness for myeloid- and lymphoid-derived hematologic malignancies. Proc Natl Acad Sci USA 114:E7554-E7563, 2017

75. Frismantas $V$, Dobay MP, Rinaldi $A$, et al: Ex vivo drug response profiling detects recurrent sensitivity patterns in drug resistant acute lymphoblastic leukemia. Blood 129:e26-e37, 2017

76. Snijder B, Vladimer Gl, Krall N, et al: Imagebased ex-vivo drug screening for patients with aggressive haematological malignancies: Interim results from a single-arm, open-label, pilot study. Lancet Haematol 4:e595-e606, 2017

77. Fischer $U$, Forster $M$, Rinaldi $A$, et al: Genomics and drug profiling of fatal TCF3-HLF-positive acute lymphoblastic leukemia identifies recurrent mutation patterns and therapeutic options. Nat Genet 47:1020-1029, 2015

78. Suryani $S$, Carol $H$, Chonghaile $T N$, et al: Cell and molecular determinants of in vivo efficacy of the BH3 mimetic ABT-263 against pediatric acute lymphoblastic leukemia xenografts. Clin Cancer Res 20: 4520-4531, 2014

79. Peirs S, Frismantas $V$, Matthijssens $F$, et al: Targeting BET proteins improves the therapeutic efficacy of BCL-2 inhibition in T-cell acute lymphoblastic leukemia. Leukemia 31:2037-2047, 2017

80. McComb S, Aguadé-Gorgorió J, Harder L, et al: Activation of concurrent apoptosis and necroptosis by SMAC mimetics for the treatment of refractory and relapsed ALL. Sci Transl Med 8: 339ra70, 2016

81. Kamel-Reid $S$, Letarte $M$, Sirard $C$, et al: $A$ model of human acute lymphoblastic leukemia in immune-deficient SCID mice. Science 246: 1597-1600, 1989

82. Rongvaux $A$, Takizawa $H$, Strowig $T$, et al: Human hemato-lymphoid system mice: Current use and future potential for medicine. Annu Rev Immunol 31:635-674, 2013

83. Liem NL, Papa RA, Milross CG, et al: Characterization of childhood acute lymphoblastic leukemia xenograft models for the preclinical evaluation of new therapies. Blood 103:3905-3914, 2004

84. Jones $L$, Carol $H$, Evans $K$, et al: A review of new agents evaluated against pediatric acute lymphoblastic leukemia by the Pediatric Preclinical Testing Program. Leukemia 30:2133-2141, 2016

85. Khaw SL, Suryani S, Evans K, et al: Venetoclax responses of pediatric $A L L$ xenografts reveal sensitivity of MLL-rearranged leukemia. Blood 128: 1382-1395, 2016

86. Tasian SK, Teachey DT, Li Y, et al: Potent efficacy of combined PI3K/mTOR and JAK or ABL inhibition in murine xenograft models of Ph-like acute lymphoblastic leukemia. Blood 129:177-187, 2017

87. Townsend EC, Murakami MA, Christodoulou A, et al: The public repository of xenografts enables discovery and randomized phase II-like trials in mice. Cancer Cell 29:574-586, 2016 [Erratum: Cancer Cell 30:183]
88. Meyer LH, Eckhoff SM, Queudeville M, et al: Early relapse in $A L L$ is identified by time to leukemia in NOD/SCID mice and is characterized by a gene signature involving survival pathways. Cancer Cell 19:206-217, 2011

89. Schmitz M, Breithaupt $P$, Scheidegger $N$, et al: Xenografts of highly resistant leukemia recapitulate the clonal composition of the leukemogenic compartment. Blood 118:1854-1864, 2011

90. le Viseur C, Hotfilder M, Bomken S, et al: In childhood acute lymphoblastic leukemia, blasts at different stages of immunophenotypic maturation have stem cell properties. Cancer Cell 14:47-58, 2008

91. Lapidot T, Sirard C, Vormoor J, et al: A cell initiating human acute myeloid leukaemia after transplantation into SCID mice. Nature 367:645-648, 1994

92. Rehe K, Wilson K, Bomken S, et al: Acute B lymphoblastic leukaemia-propagating cells are present at high frequency in diverse lymphoblast populations. EMBO Mol Med 5:38-51, 2013

93. Notta F, Mullighan CG, Wang JC, et al: Evolution of human BCR-ABL1 lymphoblastic leukaemiainitiating cells. Nature 469:362-367, 2011 [Erratum: Nature 471:254]

94. Chonghaile TN, Roderick JE, Glenfield C, et al: Maturation stage of $\mathrm{T}$-cell acute lymphoblastic leukemia determines BCL-2 versus BCL-XL dependence and sensitivity to ABT-199. Cancer Discov 4:1074-1087, 2014

95. Peirs S, Matthijssens F, Goossens $S$, et al: ABT-199 mediated inhibition of BCL-2 as a novel therapeutic strategy in T-cell acute lymphoblastic leukemia. Blood 124:3738-3747, 2014

96. Leonard JT, Rowley JSJ, Eide CA, et al: Targeting $B C L-2$ and $A B L / L Y N$ in Philadelphia chromosome-positive acute lymphoblastic leukemia. Sci Transl Med 8:354ra114-354ra114, 2016

97. Bonapace L, Bornhauser BC, Schmitz M, et al: Induction of autophagy-dependent necroptosis is required for childhood acute lymphoblastic leukemia cells to overcome glucocorticoid resistance. J Clin Invest 120:1310-1323, 2010

98. Geng H, Hurtz C, Lenz KB, et al: Self-enforcing feedback activation between BCL6 and pre-B cell receptor signaling defines a distinct subtype of acute lymphoblastic leukemia. Cancer Cell 27:409-425, 2015

99. Müschen M: Rationale for targeting the pre-Bcell receptor signaling pathway in acute lymphoblastic leukemia. Blood 125:3688-3693, 2015

100. Lu Z, Xie J, Wu G, et al: Fasting selectively blocks development of acute lymphoblastic leukemia via leptin-receptor upregulation. Nat Med 23:79-90, 2017

101. Thomas DA, O'Brien $S$, Jorgensen $J L$, et al: Prognostic significance of CD20 expression in adults with de novo precursor B-lineage acute lymphoblastic leukemia. Blood 113:6330-6337, 2009

102. DeAngelo DJ: The use of novel monoclonal antibodies in the treatment of acute lymphoblastic leukemia. Hematology (Am Soc Hematol Educ Program) 2015:400-405, 2015

103. Gökbuget $N$, Zugmaier $G$, Klinger $M$, et al: Long-term relapse-free survival in a phase 2 study of blinatumomab for the treatment of patients with minimal residual disease in B-lineage acute lymphoblastic leukemia. Haematologica 102:e132-e135, 2017

104. Duell J, Dittrich $M$, Bedke $T$, et al: Frequency of regulatory $T$ cells determines the outcome of the T-cell-engaging antibody blinatumomab in patients with B-precursor ALL. Leukemia 31:2181-2190, 2017
105. Braig F, Brandt A, Goebeler $M$, et al: Resistance to anti-CD19/CD3 BiTE in acute lymphoblastic leukemia may be mediated by disrupted CD19 membrane trafficking. Blood 129:100-104, 2017

106. Kantarjian HM, DeAngelo DJ, Stelljes $M$, et al: Inotuzumab ozogamicin (InO) vs standard of care (SC) in patients with relapsed/refractory (R/R) acute lymphoblastic leukemia (ALL): Long-term results of the phase 3 INO-VATE Study. Blood 130:2574, 2017

107. Kantarjian HM, DeAngelo DJ, Advani AS, et al: Hepatic adverse event profile of inotuzumab ozogamicin in adult patients with relapsed or refractory acute lymphoblastic leukaemia: Results from the open-label, randomised, phase 3 INO-VATE study. Lancet Haematol 4:e387-e398, 2017

108. Kantarjian H, Ravandi $F$, Short NJ, et al: Inotuzumab ozogamicin in combination with lowintensity chemotherapy for older patients with Philadelphia chromosome-negative acute lymphoblastic leukaemia: A single-arm, phase 2 study. Lancet Oncol 19:240-248, 2018

109. Lee DW, Kochenderfer JN, Stetler-Stevenson $\mathrm{M}$, et al: T cells expressing CD19 chimeric antigen receptors for acute lymphoblastic leukaemia in children and young adults: A phase 1 dose-escalation trial. Lancet 385:517-528, 2015

110. Maude SL, Frey N, Shaw PA, et al: Chimeric antigen receptor $\mathrm{T}$ cells for sustained remissions in leukemia. N Engl J Med 371:1507-1517, 2014

111. Davila $M L$, Riviere I, Wang $X$, et al: Efficacy and toxicity management of 19-28z CAR $T$ cell therapy in B cell acute lymphoblastic leukemia. Sci Transl Med 6:224ra25, 2014

112. Frishman-Levy $L$, Shemesh $A$, Bar-Sinai $A$, et al: Central nervous system acute lymphoblastic leukemia: Role of natural killer cells. Blood 125: 3420-3431, 2015

113. Rheingold $S R$, Chen $L N$, Maude $S L$, et al: Efficient trafficking of chimeric antigen receptor (CAR)-modified T cells to CSF and induction of durable CNS remissions in children with CNS/combined relapsed/refractory ALL. Blood 126:3769, 2015

114. Foà $R$, Vitale $A$, Vignetti $M$, et al: Dasatinib as first-line treatment for adult patients with Philadelphia chromosome-positive acute lymphoblastic leukemia. Blood 118:6521-6528, 2011

115. Jabbour $E$, Kantarjian $H$, Ravandi $F$, et al: Combination of hyper-CVAD with ponatinib as first-line therapy for patients with Philadelphia chromosome-positive acute lymphoblastic leukaemia: A single-centre, phase 2 study. Lancet Oncol 16: 1547-1555, 2015

116. Chalandon $Y$, Thomas $X$, Hayette $S$, et al: Randomized study of reduced-intensity chemotherapy combined with imatinib in adults with Ph-positive acute lymphoblastic leukemia. Blood 125:3711-3719, 2015

117. Chiaretti $S$, Vitale $A$, Vignetti $M$, et al: A sequential approach with imatinib, chemotherapy and transplant for adult $\mathrm{Ph}+$ acute lymphoblastic leukemia: Final results of the GIMEMA LAL 0904 study. Haematologica 101:1544-1552, 2016

118. Ravandi $F$, Othus $M, O$ O'Brien SM, et al: US intergroup study of chemotherapy plus dasatinib and allogeneic stem cell transplant in Philadelphia chromosome positive ALL. Blood Adv 1:250-259, 2016

119. Vignetti $M$, Fazi $P$, Cimino $G$, et al: Imatinib plus steroids induces complete remissions and prolonged survival in elderly Philadelphia chromosome-positive patients with acute lymphoblastic leukemia without additional chemotherapy: Results of the Gruppo Italiano Malattie Ematologiche dell'Adulto (GIMEMA) LAL0201-B protocol. Blood 109:3676-3678, 2007 
120. Martinelli G, Piciocchi $A$, Papayannidis $C$, et al: First report of the Gimema LAL1811 phase II prospective study of the combination of steroids with ponatinib as frontline therapy of ederly or unfit patients with Philadelphia chromosome-positive acute lymphoblastic leukemia. Blood 130:99, 2017

121. Borthakur G, Dombret $H$, Schafhausen $P$, et al: A phase I study of danusertib (PHA-739358) in adult patients with accelerated or blastic phase chronic myeloid leukemia and Philadelphia chromosomepositive acute lymphoblastic leukemia resistant or intolerant to imatinib and/or other second generation c-ABL therapy. Haematologica 100:898-904, 2015

122. Wylie AA, Schoepfer J, Jahnke W, et al: The allosteric inhibitor ABL001 enables dual targeting of BCR-ABL1. Nature 543:733-737, 2017

123. Pemovska $T$, Kontro $M$, Yadav $B$, et al: Individualized systems medicine strategy to tailor treatments for patients with chemorefractory acute myeloid leukemia. Cancer Discov 3:1416-1429, 2013

124. Appelmann I, Rillahan $C D$, de Stanchina $E$, et al: Janus kinase inhibition by ruxolitinib extends dasatinib-and dexamethasone-induced remissions in a mouse model of Ph+ ALL. Blood 125:1444-1451, 2015

125. Churchman ML, Low J, Qu C, et al: Efficacy of retinoids in IKZF1-Mutated BCR-ABL1 acute lymphoblastic leukemia. Cancer Cell 28:343-356, 2015

126. McClellan JS, Dove $C$, Gentles AJ, et al: Reprogramming of primary human Philadelphia chromosome-positive B cell acute lymphoblastic leukemia cells into nonleukemic macrophages. Proc Natl Acad Sci USA 112:4074-4079, 2015

127. Roberts KG, Li Y, Payne-Turner $D$, et al: Targetable kinase-activating lesions in Ph-like acute lymphoblastic leukemia. N Engl J Med 371: 1005-1015, 2014

128. Roberts KG, Pei $D$, Campana $D$, et al: Outcomes of children with BCR-ABL1-like acute lymphoblastic leukemia treated with risk-directed therapy based on the levels of minimal residual disease. J Clin Oncol 32:3012-3020, 2014

129. Roberts KG, Gu Z, Payne-Turner $D$, et al: High frequency and poor outcome of Philadelphia chromosome-like acute lymphoblastic leukemia in adults. J Clin Oncol 35:394-401, 2017

130. Herold T, Baldus CD, Gökbuget N: Ph-like acute lymphoblastic leukemia in older adults. N Engl J Med 371:2235, 2014

131. Heatley $S L$, Sadras $T$, Kok $\mathrm{CH}$, et al: High prevalence of relapse in children with Philadelphia-like acute lymphoblastic leukemia despite risk-adapted treatment. Haematologica 102:E490-E493, 2017

132. Jain $N$, Jabbour EJ, McKay $P Z$, et al: Ruxolitinib or dasatinib in combination with chemotherapy for patients with relapsed/refractory Philadelphia (Ph)-like acute lymphoblastic leukemia: A phase I-II trial. Blood 130:1322, 2017

133. Chiaretti $S$, Messina $M$, Grammatico $S$, et al: Rapid identification of BCR/ABL1-like acute lymphoblastic leukaemia patients using a predictive statistical model based on quantitative real timepolymerase chain reaction: clinical, prognostic and therapeutic implications. Br J Haematol 181:642-652, 2018

134. Klaus CR, Iwanowicz D, Johnston $D$, et al: DOT1L inhibitor EPZ-5676 displays synergistic antiproliferative activity in combination with standard of care drugs and hypomethylating agents in MLLrearranged leukemia cells. J Pharmacol Exp Ther 350:646-656, 2014

135. Benito JM, Godfrey L, Kojima K, et al: MLLrearranged acute lymphoblastic leukemias activate
BCL-2 through $\mathrm{H} 3 \mathrm{~K} 79$ methylation and are sensitive to the BCL-2-specific antagonist ABT-199. Cell Reports 13:2715-2727, 2015

136. Ackler S, Oleksijew $A$, Chen J, et al: Clearance of systemic hematologic tumors by venetoclax (Abt199) and navitoclax. Pharmacol Res Perspect 3 : e00178, 2015

137. Cruickshank MN, Ford J, Cheung LC, et al: Systematic chemical and molecular profiling of MLLrearranged infant acute lymphoblastic leukemia reveals efficacy of romidepsin. Leukemia 31:40-50, 2017

138. Messina $M$, Chiaretti $S$, Tavolaro $S$, et al: Protein kinase gene expression profiling and in vitro functional experiments identify novel potential therapeutic targets in adult acute lymphoblastic leukemia. Cancer 116:3426-3437, 2010

139. Bicocca VT, Chang BH, Masouleh BK, et al: Crosstalk between ROR 1 and the Pre-B cell receptor promotes survival of $t(1 ; 19)$ acute Iymphoblastic leukemia. Cancer Cell 22:656-667, 2012

140. Krause $S$, Pfeiffer $C$, Strube $S$, et al: Mer tyrosine kinase promotes the survival of $t(1 ; 19)$-positive acute lymphoblastic leukemia (ALL) in the central nervous system (CNS). Blood 125:820-830, 2015

141. Eldfors $S$, Kuusanmäki $H$, Kontro $M$, et al: Idelalisib sensitivity and mechanisms of disease progression in relapsed TCF3-PBX1 acute lymphoblastic leukemia. Leukemia 31:51-57, 2017

142. Deucher AM, Qi Z, Yu J, et al: BCL6 expression correlates with the $t(1 ; 19)$ translocation in B-lymphoblastic leukemia. Am J Clin Pathol 143: 547-557, 2015

143. Kim E, Hurtz C, Koehrer $S$, et al: Ibrutinib inhibits pre-BCR ${ }^{+} \mathrm{B}$-cell acute lymphoblastic leukemia progression by targeting BTK and BLK. Blood 129: 1155-1165, 2017

144. Holmfeldt $L$, Wei L, Diaz-Flores $E$, et al: The genomic landscape of hypodiploid acute lymphoblastic leukemia. Nat Genet 45:242-252, 2013

145. Safavi S, Paulsson K: Near-haploid and lowhypodiploid acute lymphoblastic leukemia: Two distinct subtypes with consistently poor prognosis. Blood 129:420-423, 2017

146. Mullighan CG, Goorha $S$, Radtke I, et al: Genome-wide analysis of genetic alterations in acute lymphoblastic leukaemia. Nature 446:758-764, 2007

147. Paulsson K, Cazier JB, Macdougall F, et al: Microdeletions are a general feature of adult and adolescent acute lymphoblastic leukemia: Unexpected similarities with pediatric disease. Proc Natl Acad Sci USA 105:6708-6713, 2008

148. Roberts KG, Morin RD, Zhang J, et al: Genetic alterations activating kinase and cytokine receptor signaling in high-risk acute lymphoblastic leukemia. Cancer Cell 22:153-166, 2012

148a. Burke MJ, Lamba JK, Pounds $S$, et al: A therapeutic trial of decitabine and vorinostat in combination with chemotherapy for relapsed/refractory acute lymphoblastic leukemia. Am J Hematol 89: 889-895, 2014

149. Nwabo Kamdje AH, Krampera M: Notch signaling in acute lymphoblastic leukemia: Any role for stromal microenvironment? Blood 118:6506-6514, 2011

150. van der Velden VH, de Launaij D, de Vries JF, et al: New cellular markers at diagnosis are associated with isolated central nervous system relapse in paediatric B-cell precursor acute lymphoblastic leukaemia. Br J Haematol 172:769-781, 2016

151. Münch V, Trentin L, Herzig J, et al: Central nervous system involvement in acute lymphoblastic leukemia is mediated by vascular endothelial growth factor. Blood 130:643-654, 2017
152. Dozzo M, Carobolante F, Donisi PM, et al: Burkitt lymphoma in adolescents and young adults: Management challenges. Adolesc Health Med Ther 8:11-29, 2016

153. Belver $L$, Ferrando $A$ : The genetics and mechanisms of $T$ cell acute lymphoblastic leukaemia. Nat Rev Cancer 16:494-507, 2016

154. Gu Y, Masiero M, Banham AH: Notch signaling: Its roles and therapeutic potential in hematological malignancies. Oncotarget 7:29804-29823, 2016

155. Zweidler-McKay PA, DeAngelo DJ, Douer D, et al: The safety and activity of BMS-906024, a gamma secretase inhibitor (GSI) with anti-notch activity, in patients with relapsed T-cell acute lymphoblastic leukemia (T-ALL): Initial results of a phase 1 trial. Blood 124:968, 2014

156. Buonamici $S$, Trimarchi $T$, Ruocco MG, et al: CCR7 signalling as an essential regulator of CNS infiltration in T-cell leukaemia. Nature 459:1000-1004, 2009

157. Piovan E, Yu J, Tosello V, et al: Direct reversal of glucocorticoid resistance by AKT inhibition in acute lymphoblastic leukemia. Cancer Cell 24:766-776, 2013

158. Mendes RD, Canté-Barrett $K$, Pieters $R$, et al: The relevance of PTEN-AKT in relation to NOTCH1directed treatment strategies in T-cell acute lymphoblastic leukemia. Haematologica 101:1010-1017, 2016

159. Daver $N$, Boumber $Y$, Kantarjian $H$, et al: A phase I/II study of the MTOR inhibitor everolimus in combination with hyperCVAD chemotherapy in patients with relapsed/refractory acute lymphoblastic leukemia. Clin Cancer Res 21:2704-2714, 2015

160. Trinquand A, Dos Santos NR, Tran Quang C, et al: Triggering the TCR developmental checkpoint activates a therapeutically targetable tumor suppressive pathway in T-cell leukemia. Cancer Discov 6:972-985, 2016

161. Pitt LA, Tikhonova AN, Hu H, et al: CXCL12producing vascular endothelial niches control acute $T$ cell leukemia maintenance. Cancer Cell 27: 755-768, 2015

162. Passaro D, Irigoyen $M$, Catherinet $C$, et al: CXCR4 Is required for leukemia-initiating cell activity in T cell acute lymphoblastic leukemia. Cancer Cell 27:769-779, 2015

163. Bond J, Graux C, Lhermitte L, et al: Early response-based therapy stratification improves survival in adult early thymic precursor acute lymphoblastic leukemia: A Group for Research on Adult Acute Lymphoblastic Leukemia Study. J Clin Oncol 35:2683-2691, 2017

164. Zhang J, Ding L, Holmfeldt $L$, et al: The genetic basis of early T-cell precursor acute lymphoblastic leukaemia. Nature 481:157-163, 2012

165. Van Vlierberghe $P$, Ambesi-Impiombato $A$, Perez-Garcia A, et al: ETV6 mutations in early immature human T cell leukemias. J Exp Med 208: 2571-2579, 2011

166. Maude SL, Dolai S, Delgado-Martin C, et al: Efficacy of JAK/STAT pathway inhibition in murine xenograft models of early T-cell precursor (ETP) acute lymphoblastic leukemia. Blood 125:1759-1767, 2015

167. Neumann M, Coskun E, Fransecky L, et al: FLT3 mutations in early T-cell precursor ALL characterize a stem cell like leukemia and imply the clinical use of tyrosine kinase inhibitors. PLoS One 8: e53190, 2013

168. Oshima K, Khiabanian $H$, da Silva-Almeida AC, et al: Mutational landscape, clonal evolution patterns, 
and role of RAS mutations in relapsed acute lymphoblastic leukemia. Proc Natl Acad Sci USA 113: 11306-11311, 2016

169. Jensen $M A$, Ferretti $V$, Grossman $R L$, et al: The $\mathrm{NCl}$ Genomic Data Commons as an engine for precision medicine. Blood 130:453-459, 2017

170. Pearson ADJ, Pfister SM, Baruchel A, et al: From class waivers to precision medicine in paediatric oncology. Lancet Oncol 18:e394-e404, 2017

171. Estey E, Levine RL, Löwenberg B: Current challenges in clinical development of "targeted therapies": The case of acute myeloid leukemia. Blood 125:2461-2466, 2015

172. Chakrabarti S, Michor F: Pharmacokinetics and drug-interactions determine optimum combination strategies in computational models of cancer evolution. Cancer Res 77:3908-3921, 2017

173. Holbeck SL, Camalier $R$, Crowell JA, et al: The National Cancer Institute ALMANAC: A comprehensive screening resource for the detection of anticancer drug pairs with enhanced therapeutic activity. Cancer Res 77:3564-3576, 2017

\section{Affiliations}

Renato Bassan, Ospedale dell'Angelo, Mestre-Venezia; Sabina Chiaretti, "Sapienza” University, Rome, Italy; Jean-Pierre Bourquin, University Children's Hospital, Zurich, Switzerland; and Daniel J. DeAngelo, Dana-Farber Cancer Institute, Boston, MA.

\section{Support}

Supported by Associazione Italiana per la Ricerca sul Cancro, Milan, Italy, Special Program Molecular Clinical Oncology-Extension program (Grant No. MCO10007) to Division of Hematology, "Sapienza" University, Rome, Italy. 


\section{AUTHORS' DISCLOSURES OF POTENTIAL CONFLICTS OF INTEREST}

New Approaches to the Management of Adult Acute Lymphoblastic Leukemia

The following represents disclosure information provided by authors of this manuscript. All relationships are considered compensated. Relationships are self-held unless noted. I = Immediate Family Member, Inst = My Institution. Relationships may not relate to the subject matter of this manuscript. For more information about ASCO's conflict of interest policy, please refer to www.asco.org/rwc or ascopubs.org/jco/site/ifc.

\section{Renato Bassan}

Honoraria: Shire, Incyte, Amgen, Pfizer

Consulting or Advisory Role: Amgen, Pfizer, Incyte

Travel, Accommodations, Expenses: Amgen, Shire, Incyte, Pfizer

Jean-Pierre Bourquin

Consulting or Advisory Role: Amgen

Travel, Accommodations, Expenses: Amgen
Daniel J. DeAngelo

Consulting or Advisory Role: Incyte, Pfizer, Bristol-Myers Squibb, Amgen, Novartis, Celgene, Shire, Immunogen, Takeda

Research Funding: Glycomimetics, Blueprint Medicines

Sabina Chiaretti

Honoraria: Shire, Incyte, Amgen, Pfizer

Consulting or Advisory Role: Amgen, Pfizer, Incyte

Travel, Accomodation, Expenses: Amgen 


\section{Acknowledgment}

We thank Francesca Carobolante, Division of Hematology, Ospedale dell'Angelo, Mestre-Venice, Italy, for support in editing the manuscript.

\section{Appendix}

Table A1. Results of Recent Trials With Pediatric Elements for Adolescent and Young Adult Patients and Adult Patients With Ph- ALL

\begin{tabular}{|c|c|c|c|c|c|c|c|c|c|}
\hline Study* & No. & $\begin{array}{l}\text { Age (years), mean } \\
\text { or median (range) }\end{array}$ & $\begin{array}{l}\text { CR } \\
(\%)\end{array}$ & DFS (\%) & CRD (\%) & OS (\%) & EFS (\%) & $\begin{array}{c}\text { FUP } \\
\text { (years) } \ddagger\end{array}$ & Annotations \\
\hline $\begin{array}{l}\text { JALSG ALL-202U } \\
\text { (Sakura T, et al: Blood } \\
\text { 120, } 2012 \text { [abstr 1464]) }\end{array}$ & 138 & $19(16-24)$ & 97 & 71 & - & 74 & - & 4 & Allo-HCT in $\mathrm{t}(4 ; 11)+$ \\
\hline $\begin{array}{l}\text { UKALL } 2003 \\
\text { (Hough R et al, Br J } \\
\text { Haematol 172:439- } \\
\text { 451, 2015) }\end{array}$ & 229 & $16-24$ & 97 & - & - & 76.4 & 72.3 & $5-y$ & $\begin{array}{l}\text { CR rate calculated upon } \\
\text { induction failures }(2.6 \%) \text {; } \\
\text { EFS correlating with MRD } \\
\text { risk class }(P=.0001)\end{array}$ \\
\hline GMALL 05/93 & 642 & $15-35$ & 88 & - & 49 & 46 & - & 5 & 07/03: intensified Peg-Asp, \\
\hline $\begin{array}{l}\text { 07/03 } \\
\text { (Goekbuget N, et al: } \\
\text { Blood 122, } 2013 \text { [abstr } \\
\text { 839]) }\end{array}$ & 887 & & 91 & & 61 & 65 & & & $\begin{array}{l}\text { dexamethasone, and HD } \\
\text { consolidation; allo-HCT in } \\
\text { HR or MRD+; } P<.05 \text { for } \\
\text { CRD and OS }\end{array}$ \\
\hline $\begin{array}{l}\text { GIMEMA } 1398 \\
\text { [Testi AM, et al: } \\
\text { Haematologica 99:259, } \\
\text { 2014 (suppl 1; abstr } \\
\text { S725)] }\end{array}$ & 61 & $18-35$ & 98 & - & - & 72.3 & - & 2 & - \\
\hline $\begin{array}{l}\text { GMALL 07/03; } \\
\text { (Goekbuget N, et al: } \\
\text { Blood 116, } 2010 \text { [abstr } \\
\text { 494]) }\end{array}$ & 1,226 & $35(15-55)$ & 91 & - & $\begin{array}{l}61 \text { (SR cohort 1) } \\
74 \text { (SR cohort 2) } \\
60 \text { (AYA cohort 1) } \\
78 \text { (AYA cohort 2) }\end{array}$ & $\begin{array}{l}60 \text { (cohort 1) } \\
67 \text { (cohort 2) } \\
68 \text { (SR cohort 1) } \\
80 \text { (SR cohort 2) } \\
77 \text { (AYA cohort 1) } \\
86 \text { (AYA cohort 2) }\end{array}$ & - & 3 & $\begin{array}{l}\text { Peg-Asp } 1,000 \text { and } 2,000 \\
\text { Ul/m } \text { (cohort } 1 \text { and } \\
\text { cohort } 2 \text { ), } \times 7 \text { in SR; allo- } \\
\text { HCT if HR or MRD+; } P< \\
.05 \text { for CRD and OS in SR } \\
\text { cohort } 2\end{array}$ \\
\hline $\begin{array}{l}\text { MDACC augmented } \\
\text { BFM (Rytting ME, et al: } \\
\text { Am J Hematol 91:819- } \\
\text { 823, 2016) }\end{array}$ & 106 & $22(13-39)$ & 93 & - & 60 & 53 & - & 5 & $\begin{array}{l}\text { Allo-HCT in t(4;11)+ or } \\
\text { MRD+; MRD- } v \text { MRD+ } \\
\text { on days 29-84: OS 75\% } v \\
\text { 40\%-22\% }(P=.004) ; \\
\text { CRD } 64 \%-63 \% \text { v } 33 \%- \\
26 \%(P=.017) ; \text { CRD/OS } \\
\text { comparable to hyper- } \\
\text { CVAD }\end{array}$ \\
\hline $\begin{array}{l}\text { US Intergroup C10403 } \\
\text { (Stock W, et al. Blood } \\
\text { 124, } 2014 \text { [abstr 796]) }\end{array}$ & 296 & $24(17-39)$ & - & - & - & 78 & 66 & 2 & $\begin{array}{l}\text { Ph-like signature: EFS, } 52 \% \\
v 81 \%(P=.04) ; \mathrm{MRD}- \\
\text { day 28: EFS, } 100 \%(P< \\
.0006)\end{array}$ \\
\hline $\begin{array}{l}\text { NOPHO ALL2008 (Toft N, } \\
\text { et al: Leukemia 32: } \\
\text { 606-615, 2018) }\end{array}$ & 221 & $26(18-45)$ & - & - & - & - & $\begin{array}{l}73 \\
87(\mathrm{SR}) \\
78(\mathrm{IR}) \\
66(\mathrm{HR}) \\
61(\mathrm{HCT})\end{array}$ & 5 & $\begin{array}{c}\text { Allo-HCT if day } 29 \mathrm{MRD}> \\
5 \% \text { or day } 79 \geq 0.1 \%\end{array}$ \\
\hline $\begin{array}{l}\text { Saudi Arabia/Egypt } \\
\text { (Alabdulwahab AS, } \\
\text { et al: Leuk Res 60:58- } \\
\text { 62, 2017) }\end{array}$ & 73 & $<50(37 \geq 21)$ & $\begin{array}{r}91 \text { (D), } \\
84 \\
(H)\end{array}$ & $\begin{array}{l}71(D) \\
42(H)\end{array}$ & - & $\begin{array}{r}73(\mathrm{D}) \\
48.5(\mathrm{H})\end{array}$ & - & 3 & $\begin{array}{l}\text { Comparing } D(n=43) \text { with } \\
H(n=30) \text {; better OS with } \\
\text { D protocol }(P=.04)\end{array}$ \\
\hline DFCl $01-175^{12}$ & 82 & $28(18-50)$ & 78 & $\begin{array}{l}66(B) \\
87(T)\end{array}$ & - & $\begin{array}{l}68(B) \\
76(T)\end{array}$ & - & 4 & $\begin{array}{l}\text { Allo-HCT in } \mathrm{t}(4 ; 11)+,+8 \\
\text { t(9;12)+; intensified L-Asp }\end{array}$ \\
\hline $\begin{array}{l}\text { DFCl 06-254 } \\
\text { (DeAngelo DJ, et al: } \\
\text { Blood 126:80, } \\
2015 \text { [abstr]) }\end{array}$ & 89 & $32(18-50)$ & 89 & 80 & - & 75 & - & 3 & $\begin{array}{l}\text { Intensified Peg-Asp } \\
\text { (toxicity reduced from } \\
2,500 \text { to } 2,000 \mathrm{Ul} / \mathrm{m}^{2} \text { and } \\
\text { from } 16 \text { to } 10 \text { doses) }\end{array}$ \\
\hline GRAALL $2003^{11}$ & 225 & $31(15-60)$ & $\begin{array}{r}93.5 \\
53(> \\
45 \\
y)\end{array}$ & - & $\begin{array}{l}61(15-45 y) \\
53(>45 y)\end{array}$ & $\begin{array}{l}60 \\
64 \text { (15-45 years) } \\
47 \text { (> } 45 \text { years) }\end{array}$ & 55 & 3.5 & $\begin{array}{l}\text { Allo-HCT in } t(4 ; 11)+, \mathrm{HR} \text { or } \\
\mathrm{MRD}>10^{-2}, \text { age } \leq 55 \\
\text { years }\end{array}$ \\
\hline $\begin{array}{l}\text { GRAALL 2003, } 2005 \\
\text { (Beldjord K, et al: Blood } \\
\text { 123:3739-3749, 2014) }\end{array}$ & 955 & $35(15-60)$ & 92 & - & - & 57 & - & 5 & $\begin{array}{l}\text { Allo-HCT in HR } \\
\text { MRD and oncogenetics } \\
\text { significantly affecting risk } \\
\text { of relapse }\end{array}$ \\
\hline \multicolumn{10}{|c|}{ (continued on following page) } \\
\hline
\end{tabular}


New Treatments for Adult ALL

Table A1. Results of Recent Trials With Pediatric Elements for Adolescent and Young Adult Patients and Adult Patients With Ph- ALL (continued)

\begin{tabular}{|c|c|c|c|c|c|c|c|c|c|c|}
\hline Study* & No. & $\begin{array}{l}\text { Age (years), mear } \\
\text { or median (range) }\end{array}$ & & $\begin{array}{l}\mathrm{CR} \\
(\%)\end{array}$ & DFS (\%) & CRD (\%) & OS (\%) & EFS (\%) & $\begin{array}{c}\text { FUP } \\
\text { (years)‡ }\end{array}$ & Annotations \\
\hline $\begin{array}{l}\text { RAALL } 2009 \\
\text { (Parovichnikova EN, } \\
\text { et al: Blood 124:3662, } \\
2014 \text { [abstr]) }\end{array}$ & 250 & $30(15-60)$ & 87 & & $\begin{array}{l}69.3 \\
71.5(<30 y) \\
61.2(\geq 30 y)\end{array}$ & - & $\begin{array}{l}65.6 \\
73.6(<30 \text { years) } \\
52.7 \text { ( } \geq 30 \text { years) }\end{array}$ & - & 4 & Allo-HCT in HR \\
\hline $\begin{array}{l}\text { PETHEMA HR-11 } \\
\text { (Ribera J-M, et al: Blood } \\
\text { 128:180, } 2016 \text { [abstr]) }\end{array}$ & 126 & $30-60$ & 86 & & $\begin{array}{l}40 \text { (L-Asp) } \\
58 \text { (Peg-Asp) }\end{array}$ & - & $\begin{array}{l}60 \text { (L-Asp) } \\
57 \text { (Peg-Asp) }\end{array}$ & - & 3 & $\begin{array}{l}\text { HR only, for allo-HCT if } \\
\text { MRD+; comparable } \\
\text { MRD response L-Asp } v \\
\text { Peg-Asp }\end{array}$ \\
\hline $\begin{array}{l}\text { NILG 10/07 } \\
\text { (Bassan R, et al: Blood } \\
\text { 128:176, 2016, [abstr]) }\end{array}$ & 163 & $41(17-67)$ & & 87 & $\begin{array}{l}55 \\
48(B) \\
61(T)\end{array}$ & - & $\begin{array}{l}52 \\
48(B) \\
74(T)\end{array}$ & - & 5 & $\begin{array}{l}\text { Allo-HCT in MRD+ or very } \\
\text { HR; MRD highly } \\
\text { predictive of outcome }\end{array}$ \\
\hline $\begin{array}{l}\text { JALSG ALL 202-O } \\
\text { (Sakura T, et al: } \\
\text { Leukemia 32: 626-632, } \\
\text { 2018; 2017) }\end{array}$ & 344 & $24-65$ & & 86 & 42 & - & 52 & - & 5 & $\begin{array}{l}\text { Phase III trial (MTX } 0.5 v \\
3 \mathrm{~g} / \mathrm{m}^{2} \text { : DFS } 32 \% \text { v } 56 \% \\
P=.015)\end{array}$ \\
\hline
\end{tabular}

NOTE. Dashes indicate no data.

Abbreviations: ALL, acute lymphoblastic leukemia; allo-HCT, allogeneic hematopoietic cell transplantation; B, B-precursor ALL; CR, complete remission; CRD, duration of complete remission; D, Dana Farber consortium protocol; DFCl, Dana Farber Cancer Institute; DFS, disease-free survival; EFS, event-free survival; FUP, follow-up; GIMEMA, Gruppo Italiano Malattie Ematologiche dell'Adulto; GMALL, German Multicenter Group for Adult ALL; GRAALL, Group for Research on Adult ALL; H, hyperCVAD protocol; hyper-CVAD, hyperfractionated cyclophosphamide, vincristine, doxorubicin, dexamethasone; HD, high dose; HR, high risk; IR, intermediate risk; JALSG, Japan Adult Leukemia Study Group; L-Asp, L-asparaginase; MDACC, MD Anderson Cancer Center; MRD, minimal residual disease; MTX, methotrexate; NILG, Northern Italy Leukemia Group; NOPHO, Nordic Society of Pediatric Haematology and Oncology; OS, overall survival; Peg-Asp, pegylated asparaginase; Ph, Philadelphia chromosome; PETHEMA, Programa Español de Tratamientos en Hematologia; RAALL, Russian Adult ALL Group; SR, standard risk; T, T-precursor ALL.

* Studies are ordered by increasing patient age. There were a minimum of 50 patients; outcome estimates at $\geq 3$ years except GIMEMA 1398 and US Intergroup

C10403, for which 2-year results are reported.

†Age given as mean (range) or range.

$\ddagger$ Number of years of CR/DFS/CRD/OS/EFS estimates. 
Table A2. Registered or ongoing trials $(n=25)$ With Innovative Therapeutics For Relapsed/Refractory, MRD-Positive or Untreated Adult B-Precursor Ph- ALL*

\begin{tabular}{|c|c|c|c|c|c|c|}
\hline Institution/Trial Denomination & $\begin{array}{l}\text { ClinicalTrials. } \\
\text { gov Identifier }\end{array}$ & $\begin{array}{c}\text { Patient Age, Years (No.), } \\
\text { ALL Subset }\end{array}$ & Study Drug & $\begin{array}{l}\text { Associated } \\
\text { Chemotherapy }\end{array}$ & $\begin{array}{l}\text { Trial } \\
\text { Design } \\
\text { (phase) }\end{array}$ & $\begin{array}{l}\text { Primary Objective/ } \\
\text { Outcome Measures }\end{array}$ \\
\hline \multicolumn{7}{|l|}{ Relapsed/refractory } \\
\hline $\begin{array}{l}\text { University of California/UCDCC } \\
266\end{array}$ & NCT02997761 & $\geq 18(20)$ & $\begin{array}{l}\text { Ibrutinib (BCR inhibitor), } \\
\text { blinatumomab (CD19 } \times \text { CD3 } \\
\text { bispecific antibody) }\end{array}$ & No & ॥ & $\mathrm{CR}$ rate \\
\hline Amgen/20130265 & NCT02412306 & $\geq 18(57)$ & Blinatumomab & No & |/II & $\begin{array}{l}\text { Dose-limiting toxicities } \\
\text { and CR rate }\end{array}$ \\
\hline MDACC/2015-0870 & NCT03094611 & $\geq 12$ (48), CD22+ ALL & $\begin{array}{l}\text { Inotuzumab (calicheamicin- } \\
\text { conjugated CD22 } \\
\text { immunotoxin) }\end{array}$ & No & ॥ & $\mathrm{CR}$ rate \\
\hline NCI/COG-ALL1331 & NCT02101853 & 1-30 (598), including AYA & Blinatumomab & Yes (intensive) & III & Disease-free survival \\
\hline MDACC/2014-0521 & NCT02420717 & $\geq 10$ (92), Ph-like, short - & $\begin{array}{l}\text { Ruxolitinib (JAK2 inhibitor)/ } \\
\text { Dasatinib }\end{array}$ & $\begin{array}{l}\text { Yes (hyper- } \\
\text { CVAD) }\end{array}$ & ॥ & $\mathrm{CR}$ rate \\
\hline COG & NCT02723994 & $\geq 10$ (170); Ph-like & Ruxolitinib (JAK2 inhibitor) & $\begin{array}{l}\text { Yes (modified } \\
\text { aBFM } \\
\text { regimen) }\end{array}$ & $\|$ & $\begin{array}{l}\text { Event-free survival at } \\
3 \text { years }\end{array}$ \\
\hline $\mathrm{NCl}$ & NCT02883049 & 1-31 (5437), Ph-like & Dasatinib & Yes & III & Outcome description \\
\hline SWOG/S1312 & NCT01925131 & $\begin{array}{l}\geq 18+(38), C D 22+\text {, any } \\
\text { subset }\end{array}$ & Inotuzumab & Yes (CVP) & 1 & Maximum tolerated dose \\
\hline Xencor/XmAb14045-01 & NCT02730312 & $\begin{array}{l}\geq 18(66), C D 123+\text {, any } \\
\text { subset }\end{array}$ & XmAb14045 (CD123 × CD3) & No & 1 & Maximum tolerated dose \\
\hline $\begin{array}{l}\text { Janssen Research and } \\
\text { Development/CR107241 }\end{array}$ & NCT02454270 & $\begin{array}{l}\geq 18 \text { (221), any type } \\
\text { (including B-cell } \\
\text { lymphoma) }\end{array}$ & $\begin{array}{l}\text { Duvortuxizumab (CD19 } \times \text { CD3 } \\
\text { dual-affinity retargeting } \\
\text { protein) }\end{array}$ & No & 1 & $\begin{array}{l}\text { Recommended phase II } \\
\text { dose/overall response } \\
\text { rate }\end{array}$ \\
\hline MDACC/2010-0091 & NCT01371630 & $\geq 60(206)$ & Inotuzumab & $\begin{array}{l}\text { Yes (low } \\
\text { intensity) }\end{array}$ & $|/| \mid$ & Maximum tolerated dose \\
\hline NCI/ALL1131 & NCT02883049 & $\begin{array}{l}\text { 1-30 (5437), including AYA, } \\
\text { HR or Ph-like }\end{array}$ & Dasatinib (Ph-like) & $\begin{array}{l}\text { Yes (intensive } \\
\text { BFM-type) }\end{array}$ & III & Improved DFS \\
\hline $\begin{array}{l}\text { University of California/UCDCC } \\
246\end{array}$ & NCT02293109 & $18-64(18)$ & Carfilzomib & $\begin{array}{l}\text { Yes (hyper- } \\
\text { CVAD) }\end{array}$ & I & Safety, tolerability, dosing \\
\hline $\mathrm{DFCl} / 14-200$ & NCT02228772 & $51-75(28)$ & $\begin{array}{l}\text { Ixazomib (20 S proteasome } \\
\text { inhibitor) }\end{array}$ & Yes & I & $\begin{array}{l}\text { Safety and maximum } \\
\text { tolerated dose }\end{array}$ \\
\hline MDACC/2014-0845 & NCT02877303 & $\geq 14(60)$ & Blinatumomab & $\begin{array}{l}\text { Yes (hyper- } \\
\text { CVAD) }\end{array}$ & ॥ & Relapse-free survival \\
\hline MDACC/2010-0708 & NCT01363128 & Any age (80) & Ofatumumab (CD20) & $\begin{array}{l}\text { Yes (hyper- } \\
\text { CVAD) }\end{array}$ & ॥ & ALL control and safety \\
\hline MDACC/2014-0396 & NCT02419469 & $12-30(100)$, including AYA & Ofatumumab (CD20) & $\begin{array}{l}\text { Yes } \\
\text { (augmented } \\
\text { BFM) }\end{array}$ & ॥ & Relapse-free survival \\
\hline \multicolumn{7}{|l|}{ Unspecified disease status } \\
\hline $\begin{array}{l}\text { Regeneron Pharmaceuticals/ } \\
\text { R-1979-ONC-1504 }\end{array}$ & NCT02651662 & $\begin{array}{l}\geq 18(100), C D 20 \text { ALL (any } \\
\text { subset) }\end{array}$ & $\begin{array}{l}\text { REG2810 (anti-PD-1), } \\
\text { REGN1979 (CD20 × CD3) }\end{array}$ & Not reported & 1 & $\begin{array}{l}\text { Treatment-emergent } \\
\text { adverse events }\end{array}$ \\
\hline
\end{tabular}

Abbreviations: aBFM, augmented Berlin-Frankfurt-Münster; ALL, acute lymphoblastic leukemia; AYA, adolescents and young adults; BCR, B-cell receptor; BFM, BerlinFrankfurt-Münster; COG, Children's Oncology Group; CR, complete remission; CVP, cyclophosphamide, vincristine, prednisone; CR, complete response; DFCI, Dana Farber Cancer Institute; DFS, disease-free survival; ECOG, Eastern Cooperative Oncology Group; hyper-CVAD, hyperfractionated cyclophosphamide, vincristine, doxorubicin, dexamethasone; MDACC, MD Anderson Cancer Center; MRD, minimal residual disease; $\mathrm{NCl}$, National Cancer Institute; OS, overall survival; Ph, Philadelphia chromosome; SWOG, Southwest Oncology Group.

*Ph+ ALL is included when "any subset" is added (extracted from ClinicalTrials.gov website, accessed April 2017). 
Table A3. Registered or Ongoing Trials ( $n=7$ ) With Innovative Therapeutics for Relapsed/Refractory or Untreated Adult B-Precursor Ph+ Acute Lymphoblastic Leukemia*

\begin{tabular}{|c|c|c|c|c|c|c|}
\hline $\begin{array}{l}\text { Institution/Trial } \\
\text { Denomination }\end{array}$ & $\begin{array}{l}\text { ClinicalTrials.gov } \\
\text { identifier }\end{array}$ & Patient Age, Years (No.) & Study Drug & $\begin{array}{l}\text { Associated } \\
\text { Chemotherapy }\end{array}$ & $\begin{array}{c}\text { Trial } \\
\text { Design } \\
\text { (phase) }\end{array}$ & $\begin{array}{c}\text { Primary Objective/Outcome } \\
\text { Measures }\end{array}$ \\
\hline \multicolumn{7}{|l|}{ Relapsed/refractory } \\
\hline $\begin{array}{l}\text { Northwestern } \\
\text { University/NU } \\
15 \mathrm{H} 13\end{array}$ & NCT02819804 & $\geq 18(22)$ & $\begin{array}{l}\text { Nivolumab (with } \\
\text { dasatinib) }\end{array}$ & No & I & Dose-limiting toxicity \\
\hline $\begin{array}{l}\text { Novartis } \\
\text { Pharmaceuticals/ } \\
\text { CABL001X2101 }\end{array}$ & NCT02081378 & $\geq 18(250)$ & $\begin{array}{l}\text { ABL001 (selected } \\
\text { allosteric ABL1 } \\
\text { inhibitor) }\end{array}$ & No & । & Dose-limiting toxicity \\
\hline Danusertib & $\begin{array}{l}\text { EudraCT number } \\
2007-004070- \\
18\end{array}$ & $\geq 18$ (37) & Danusertib & No & । & Dose-limiting toxicity \\
\hline MDACC/2014-0435 & NCT02311998 & $\geq 18$ (80), CD22+ & $\begin{array}{l}\text { Inotuzumab (with } \\
\text { bosutinib) }\end{array}$ & No & $|/| I$ & Maximum tolerated dose \\
\hline $\begin{array}{l}\text { University Health } \\
\text { Network Toronto/ } \\
\text { OZM-051 }\end{array}$ & NCT01914484 & $\geq 18$ (32) & $\begin{array}{l}\text { Ruxolitinib (with } \\
\text { nilotinib) }\end{array}$ & No & I/II & $\begin{array}{l}\text { Maximum tolerated dose/major } \\
\text { cytogenetic response }\end{array}$ \\
\hline \multicolumn{7}{|l|}{ Untreated } \\
\hline GIMEMA/D-ALBA & NCT02003222 & $\geq 18(60)$ & $\begin{array}{l}\text { Blinatumomab (after } \\
\text { dasatinib) }\end{array}$ & No & II & $\begin{array}{l}\text { MRD negativity after induction at } \\
\text { two cycles of blinatumomab }\end{array}$ \\
\hline MSKCC/14-272 & NCT02494882 & $\begin{array}{l}\geq 40(12) \text { (patients with } \\
\quad \text { relapsed disease } \\
\quad \text { allowed) }\end{array}$ & $\begin{array}{l}\text { Ruxolitinib (with } \\
\text { dasatinib) }\end{array}$ & No & I & Clinical response \\
\hline $\begin{array}{l}\text { University of Utah/ } \\
\mathrm{HCl} 85188\end{array}$ & NCT02815059 & $\geq 60(24)$ & $\begin{array}{l}\text { Ibrutinib (with } \\
\text { dasatinib) }\end{array}$ & No & I & Adverse events \\
\hline
\end{tabular}

Abbreviations: GIMEMA; Gruppo Italiano Malattie Ematologiche dell'Adulto; MDACC, MD Anderson Cancer Center; MSKCC, Memorial Sloan Kettering Cancer Center; MRD, minimal residual disease; $\mathrm{Ph}+$, positive for Philadelphia chromosome.

* Extracted from ClinicalTrials.gov website, accessed April 2017.

Table A4. Registered or Ongoing Trials $(n=4)$ With Innovative Therapeutics for Relapsed/Refractory or Untreated Adult T-Precursor Acute Lymphoblastic Leukemia*

\begin{tabular}{|c|c|c|c|c|c|c|}
\hline $\begin{array}{l}\text { Institution/Trial } \\
\text { Denomination }\end{array}$ & $\begin{array}{l}\text { ClinicalTrials.gov } \\
\text { Identifier }\end{array}$ & $\begin{array}{c}\text { Patient Age, Years } \\
\text { (No.) }\end{array}$ & Study Drug & $\begin{array}{c}\text { Associated } \\
\text { Chemotherapy }\end{array}$ & $\begin{array}{l}\text { Trial Design } \\
\text { (phase) }\end{array}$ & $\begin{array}{l}\text { Primary Objective/ } \\
\text { Outcome Measures }\end{array}$ \\
\hline \multicolumn{7}{|l|}{ Relapsed/refractory } \\
\hline $\begin{array}{l}\text { Washington } \\
\text { University/ } \\
201606146\end{array}$ & NCT02763384 & $\geq 18(20)$ & BL-8040 (CXCR-4 inhibitor) & Yes (nelarabine) & II & Safety and tolerability \\
\hline Eli Lilly and Co./14548 & NCT02518113 & $\begin{array}{l}\geq 2 \text { (92, including } \\
\text { adults) }\end{array}$ & $\begin{array}{l}\text { LY3039478 (NOTCH inhibitor; } \\
\text { with dexamethasone) }\end{array}$ & No & $|/| \mid$ & $\begin{array}{l}\text { Dose-limiting } \\
\text { toxicities/CR }\end{array}$ \\
\hline Sanofi/ACT14596 & NCT02999633 & $\geq 16$ (39) & Isatuximab (CD38) & No & II & Objective response rate \\
\hline \multicolumn{7}{|l|}{ Untreated } \\
\hline NCI/AALL1231 & NCT02112916 & $\begin{array}{l}\text { Age } 2-30(1,400) \\
\text { including AYA }\end{array}$ & Bortezomib & $\begin{array}{l}\text { Yes (intensive, } \\
\text { BFM-type) }\end{array}$ & III & $\begin{array}{l}\text { Improved event-free } \\
\text { survival }\end{array}$ \\
\hline
\end{tabular}

Abbreviations: AYA, adolescents and young adults; B, B-precursor ALL; BFM, Berlin-Frankfurt-Münster; CR, complete response; NCI, National Cancer Institute;

T, T-precursor ALL.

* Extracted from ClinicalTrials.gov website, accessed April 2017. 
Table A5. Registered or Ongoing Trials ( $n=13$ ) With Innovative Therapeutics for Relapsed/Refractory, MRD-Positive or Untreated Adult ALL, Unspecified Subset and/ or Other Leukemias*

\begin{tabular}{|c|c|c|c|c|c|c|}
\hline Institution/Trial Denomination & $\begin{array}{l}\text { ClinicalTrials.gov } \\
\text { Identifier }\end{array}$ & $\begin{array}{l}\text { Patient Age, Years } \\
\text { (No.), ALL Subset }\end{array}$ & Study Drug & $\begin{array}{l}\text { Associated } \\
\text { Chemotherapy }\end{array}$ & $\begin{array}{l}\text { Trial Design } \\
\text { (phase) }\end{array}$ & $\begin{array}{l}\text { Primary Objective/ } \\
\text { Outcome Measures }\end{array}$ \\
\hline \multicolumn{7}{|l|}{ Relapsed/refractory } \\
\hline ADC Therapeutics/301-002 & NCT02588092 & $\geq 18(60), C D 25+A L L$ & $\begin{array}{l}\text { ADCT-301 (PBD- } \\
\text { conjugated CD25 } \\
\text { immunotoxin) }\end{array}$ & No & 1 & Dose-limiting toxicity \\
\hline $\begin{array}{l}\text { Children's Mercy Hospital/ } \\
\text { MERCY01 }\end{array}$ & NCT02535806 & 1-39 (10), including AYA & Bortezomib & Yes & II & Adverse events \\
\hline $\begin{array}{l}\text { OHSU Knight Cancer Institute/ } \\
\text { IRB00007195 }\end{array}$ & NCT01620216 & $\begin{array}{l}\geq 18 \text { (24), including } \\
\text { nonlymphoid } \\
\text { leukemia }\end{array}$ & $\begin{array}{l}\text { Dasatinib or nilotinib or } \\
\text { sunitinib or sorafenib } \\
\text { or ponatinib (based } \\
\text { on kinase inhibition } \\
\text { profile obtained on } \\
\text { primary patient } \\
\text { samples) }\end{array}$ & No & II & $\begin{array}{l}\text { Clinical activity } \\
\text { (decrease of } \\
\geq 25 \% \text { in bone } \\
\text { marrow blast } \\
\text { counts) }\end{array}$ \\
\hline Daiiki Sankyo/DS3032-A-U102 & NCT02319369 & $\begin{array}{l}\geq 18 \text { (100), including } \\
\text { nonlymphoid } \\
\text { leukemia }\end{array}$ & $\begin{array}{l}\text { DS302-b (MDM2 } \\
\text { inhibitor) }\end{array}$ & No & 1 & $\begin{array}{l}\text { Maximum tolerated } \\
\text { dose }\end{array}$ \\
\hline $\begin{array}{l}\text { Children's Hospital of } \\
\text { Philadelphia/10-007444 }\end{array}$ & NCT01162551 & $\begin{aligned} & \leq 25(17), \text { including } \\
& \text { AYA; second/greater } \\
& \text { relapse) }\end{aligned}$ & $\begin{array}{l}\text { Sirolimus (mTOR } \\
\text { inhibitor) }\end{array}$ & $\begin{array}{l}\text { Yes (oral } \\
\text { methotrexate) }\end{array}$ & II & Efficacy and toxicity \\
\hline $\mathrm{NCl} / 150093$ & NCT02390752 & $\begin{array}{l}\text { 3-35 (45), including } \\
\text { AYA, nonlymphoid } \\
\text { leukemia/other } \\
\text { tumors) }\end{array}$ & $\begin{array}{l}\text { PLX3397 } \\
\quad \text { (multitargeted TKI) }\end{array}$ & No & $1 / I 1$ & $\begin{array}{l}\text { Determine phase II } \\
\text { dose/antitumor } \\
\text { activity }\end{array}$ \\
\hline $\begin{array}{l}\text { University of Washington/ } \\
\quad 9226\end{array}$ & NCT02551718 & $\begin{array}{l}\geq 3(15), \text { including } \\
\text { adults, nonlymphoid } \\
\text { leukemias, prior } \\
\text { exhaustion of two } \\
\text { treatment lines }\end{array}$ & $\begin{array}{l}\text { Various agentst (based } \\
\text { on high-throughput } \\
\text { drug sensitivity } \\
\text { assay) }\end{array}$ & Various agents & Pilot & $\begin{array}{l}\text { Feasibility within } 21 \\
\text { days (drug } \\
\text { combination) }\end{array}$ \\
\hline NCl/COG ADVL1411 & NCT02116777 & $\begin{array}{l}\text { 1-30 (148), including } \\
\text { AYA and solid tumors }\end{array}$ & $\begin{array}{l}\text { Talazoparib (PARP } \\
\text { inhibitor) }\end{array}$ & $\begin{array}{l}\text { Yes } \\
\text { (temozolomide) }\end{array}$ & $1 / I I$ & $\begin{array}{l}\text { Maximum tolerated } \\
\text { dose and } \\
\text { antitumor activity }\end{array}$ \\
\hline MDACC/2014-0731 & NCT02392572 & $\begin{array}{l}\geq 18 \text { (120), including } \\
\text { nonlymphoid } \\
\text { leukemias }\end{array}$ & $\begin{array}{l}\text { ONC201 (DRD2 } \\
\text { inhibitor) }\end{array}$ & No & $\mid / I I$ & $\begin{array}{l}\text { Maximum tolerated } \\
\text { dose }\end{array}$ \\
\hline MDACC/2013-0116 & NCT02089230 & $\begin{array}{l}\geq 18 \text { (57), including } \\
\text { nonlymphoid } \\
\text { leukemias, not } \\
\text { suitable for standard } \\
\text { therapy }\end{array}$ & $\begin{array}{l}\text { MEK } 162 \text { (MEK } \\
\text { inhibitor) }\end{array}$ & No & $1 / I I$ & $\begin{array}{l}\text { Maximum tolerated } \\
\text { dose }\end{array}$ \\
\hline \multicolumn{7}{|l|}{ MRD positive } \\
\hline $\begin{array}{l}\text { University of Washington/ } \\
9458\end{array}$ & NCT02767934 & $\geq 18(21)$ & $\begin{array}{l}\text { Pembrolizumab (anti- } \\
\text { PD-L1) }\end{array}$ & No & II & MRD negativity \\
\hline $\begin{array}{l}\text { Gilead Sciences/GS-US-339- } \\
\quad 1560\end{array}$ & NCT02404220 & $\geq 18$ (35) & $\begin{array}{l}\text { Entospletinib (SYK } \\
\text { inhibitor) }\end{array}$ & $\begin{array}{l}\text { Yes (vincristine, } \\
\text { prednisone) }\end{array}$ & 1 & $\begin{array}{l}\text { Adverse events and } \\
\text { dose-limiting } \\
\text { toxicities }\end{array}$ \\
\hline \multicolumn{7}{|l|}{ Untreated } \\
\hline $\begin{array}{l}\text { Medical College of Wisconsin/ } \\
\text { PRO25835 }\end{array}$ & NCT02578511 & $\geq 18$ (18) & Ixazomib & $\begin{array}{l}\text { Yes (POMP-D } \\
\text { maintenance) }\end{array}$ & 1 & $\begin{array}{l}\text { Maximum tolerated } \\
\text { dose }\end{array}$ \\
\hline
\end{tabular}

Abbreviations: ALL, acute lymphoblastic leukemia; COG, Children's Oncology Group; MDACC, MD Anderson Cancer Center; MRD, minimal residual disease; NCl, National Cancer Institute; OHSU, Ohio State University; NCl, National Cancer Institute; PBD, pyrrolobenzodiazepine dimer; TKI, tyrosine kinase inhibitor.

* Extracted from ClinicalTrials.gov website, accessed April 2017.

†Afatinib, arsenic trioxide, axitinib, bexarotene, bosutinib, cabazitaxel, cabozantinib, carfilzomib, ceritinib, crizotinib, dabrafenib, dasatinib, erlotinib, everolimus, gefitinib, imatinib, lapatinib, nilotinib, pazopanib, ponatinib, rapamycin, regorafenib, romidepsin, ruxolitinib, sorafenib, sunitinib, temsirolimus, trametinib, tretinoin. 
Table A6. Registered or Ongoing trials ( $n=12$ ) With Innovative Therapeutics After HCT Relapse and After, During or Before HCT in Adult ALL*

\begin{tabular}{|c|c|c|c|c|c|c|}
\hline Institution/Trial Denomination & $\begin{array}{l}\text { ClinicalTrials. } \\
\text { gov Identifier }\end{array}$ & $\begin{array}{l}\text { Patient Age, Years } \\
\text { (No.), ALL Subset }\end{array}$ & Study Drug & $\begin{array}{l}\text { Associated } \\
\text { Chemotherapy }\end{array}$ & $\begin{array}{l}\text { Trial Design } \\
\text { (phase) }\end{array}$ & $\begin{array}{l}\text { Primary Objective/ } \\
\text { Outcome Measures }\end{array}$ \\
\hline \multicolumn{7}{|l|}{ After HCT relapse } \\
\hline MSKCC/11-038 & NCT01430390 & $\begin{array}{l}\text { Any age (12), CD19+ } \\
\text { BCP ALL or } \\
\text { lymphoma }\end{array}$ & $\begin{array}{l}\text { Expanded EBV- } \\
\text { specific } \\
\text { allogeneic } \\
\text { T-cytotoxic cells }\end{array}$ & No & । & $\begin{array}{l}\text { Safety/persistence of } \\
\text { escalating doses of } \\
\text { allogeneic } \\
\text { modified T cells }\end{array}$ \\
\hline $\begin{array}{l}\text { Masonic Cancer Center, } \\
\text { University of Minnesota/ } \\
\text { HM2013-12 }\end{array}$ & NCT01885897 & $\begin{array}{c}\geq 18(61), \text { ALL and } \\
\text { other leukemias }\end{array}$ & $\begin{array}{l}\text { ALT-803 (IL-15 } \\
\text { superagonist } \\
\text { complex) }\end{array}$ & No & $|/| \mid$ & $\begin{array}{l}\text { Safety/efficacy, } \\
\text { toxicity, incidence } \\
\text { of acute and } \\
\text { chronic GVHD }\end{array}$ \\
\hline $\begin{array}{l}\text { Case Comprehensive Cancer } \\
\text { Center/CASE1916 }\end{array}$ & NCT03104491 & $\begin{array}{l}\text { 16-75 (44), CD22+ BCP } \\
\quad \text { ALL }\end{array}$ & $\begin{array}{l}\text { Inotuzumab } \\
\text { ozogamicin } \\
\text { (calicheamicin- } \\
\text { conjugated anti- } \\
\text { CD22) }\end{array}$ & No & $|/| \mid$ & $\begin{array}{l}\text { Maximum tolerated } \\
\text { dose, } \\
\text { posttransplant } \\
\text { relapse, response } \\
\text { rate }\end{array}$ \\
\hline \multicolumn{7}{|l|}{ After HCT } \\
\hline $\begin{array}{l}\text { University of Colorado, Denver/ } \\
\text { NCl-2013-00824 }\end{array}$ & NCT01841333 & $\begin{array}{l}\geq 18(28), \text { ALL and } \\
\text { AML }\end{array}$ & $\begin{array}{l}\text { PF-04449913 } \\
\text { (Hedgehog } \\
\text { inhibitor) }\end{array}$ & No & $\|$ & $\begin{array}{l}\text { RFS and remission } \\
\text { duration }\end{array}$ \\
\hline $\begin{array}{l}\text { Sidney Kimmel Comprehensive } \\
\text { Cancer Center/IRB00125679 }\end{array}$ & NCT03114865 & $\begin{array}{l}\geq 18 \text { (12), CD19+ BCP } \\
\text { ALL, HR and/or } \\
\text { MRD+ before HCT }\end{array}$ & Blinatumomab & No & 1 & $\begin{array}{l}\text { OSOS, DFS, MRD } \\
\text { response }\end{array}$ \\
\hline MDACC/2015-0576 & NCT02807883 & $\begin{array}{l}\text { 18-70 (30), BCP ALL, } \\
\text { HCT beyond CR1 or } \\
\text { MRD+ }\end{array}$ & Blinatumomab & No & $\|$ & $\begin{array}{l}\text { Feasibility, OS and } \\
\text { PFS }\end{array}$ \\
\hline Fate Therapeutics/PT-001 & NCT02743351 & $\begin{array}{l}\text { 18-70 (70), ALL and } \\
\text { AML }\end{array}$ & $\begin{array}{l}\text { ProTmune } \\
\text { (FT1050/PGE2 } \\
\text { inhibitor and } \\
\text { FT4145/CXCR4 } \\
\text { inducer, } \\
\text { enhancing } \\
\text { programmed T- } \\
\text { cell alloreactivity } \\
\text { and antitumoral } \\
\text { properties) }\end{array}$ & No & $|/| 1$ & $\begin{array}{l}\text { Adverse event, acute } \\
\text { GvHD CMV } \\
\text { viremia and } \\
\text { disease, febrile } \\
\text { neutropenia }\end{array}$ \\
\hline \multicolumn{7}{|l|}{ During or before $\mathrm{HCT}$} \\
\hline $\begin{array}{l}\text { Instituto Nacional de Ciencias } \\
\text { Medicas y Nutricion Salvador } \\
\text { Zubiran/INCMNSZ REF } 917\end{array}$ & NCT02605460 & $\begin{array}{l}\text { 18-60 (20), ALL and } \\
\text { AML }\end{array}$ & CXCR-4 antagonist & $\begin{array}{l}\text { Yes (busulfan, } \\
\text { cyclophosphamide) }\end{array}$ & II & OS and DFS \\
\hline Kiadis Pharma/CR-AIR-009 & NCT02999854 & $\begin{array}{l}\text { 18-70 (195), ALL and } \\
\text { AML }\end{array}$ & $\begin{array}{l}\text { ATIR101 } \\
\text { (haploidentical } \\
\text { graft depleted of } \\
\text { T-alloreactive } \\
\text { cells) }\end{array}$ & $\begin{array}{l}\text { Yes ( } v \text { post-HCT } \\
\text { cyclophosphamide } \\
\text { arm) }\end{array}$ & III & $\begin{array}{l}\text { GvHD, RFS and OS, } \\
\text { transplant } \\
\text { mortality }\end{array}$ \\
\hline Kiadis Pharma/CR-AIR-008 & NCT02500550 & $\begin{array}{l}\text { 18-65 (15), ALL and } \\
\text { AML }\end{array}$ & ATIR101 & No & $\|$ & $\begin{array}{l}\text { Incidence of grade III/ } \\
\text { IV GvHD, time to } \\
\text { T-cell reconstitution, } \\
\text { transplant-related } \\
\text { mortality, relapse } \\
\text { and survival rates }\end{array}$ \\
\hline $\begin{array}{l}\text { First Affiliated Hospital of } \\
\text { Wenzhou Medical University/ } \\
20170316\end{array}$ & NCT03110640 & $\begin{array}{l}\text { 5-70 (20), CD19+ BCP } \\
\text { ALL, other leukemia }\end{array}$ & $\begin{array}{l}\text { Autologous anti- } \\
\text { CD19 CAR-T } \\
\text { followed by } \\
\text { allogeneic HCT }\end{array}$ & $\begin{array}{l}\text { Yes (fludarabine, } \\
\text { cyclophosphamide) }\end{array}$ & 1 & $\begin{array}{l}\text { Safety/feasibility of } \\
\text { autologous CD19 } \\
\text { CAR T cells before } \\
\text { HCT }\end{array}$ \\
\hline $\begin{array}{l}\text { Bellicum Pharmaceuticals/BP-HM- } \\
001\end{array}$ & NCT01744223 & $\begin{array}{l}\text { 18-65 (36), ALL and } \\
\text { AML }\end{array}$ & $\begin{array}{l}\text { BPX-501 modified } \\
\text { donor T cells } \\
\text { reactive to } \\
\text { AP1903 self- } \\
\text { destruct switch } \\
\text { (mismatch } \\
\text { donors) }\end{array}$ & No & $|/| \mid$ & $\begin{array}{l}\text { BPX-501 dose that } \\
\text { produces no more } \\
\text { than day } 10045 \% \\
\text { grade II-IV aGVHD, } \\
\text { OS and DFS, GVHD } \\
\text { response to } \\
\text { AP1903 }\end{array}$ \\
\hline
\end{tabular}

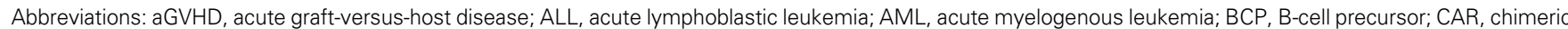
antigen receptor; CMV, cytomegalovirus; DFS, disease-free survival; EBV, Epstein-Barr virus; GvHD, graft-versus-host disease; HCT, hematopoietic cell transplantation; HR, high risk; MDACC, MD Anderson Cancer Center; MSKCC, Memorial Sloan Kettering Cancer Center; OS, overall survival; PFS, progression-free survival; RFS, relapsefree survival.

*Extracted from ClinicalTrials.gov website, accessed April 2017. 
Table A7. Registered or Ongoing Trials $(n=45)$ With Cellular Immunotherapy for Relapsed/Refractory or MRD-Positive Adult ALL*

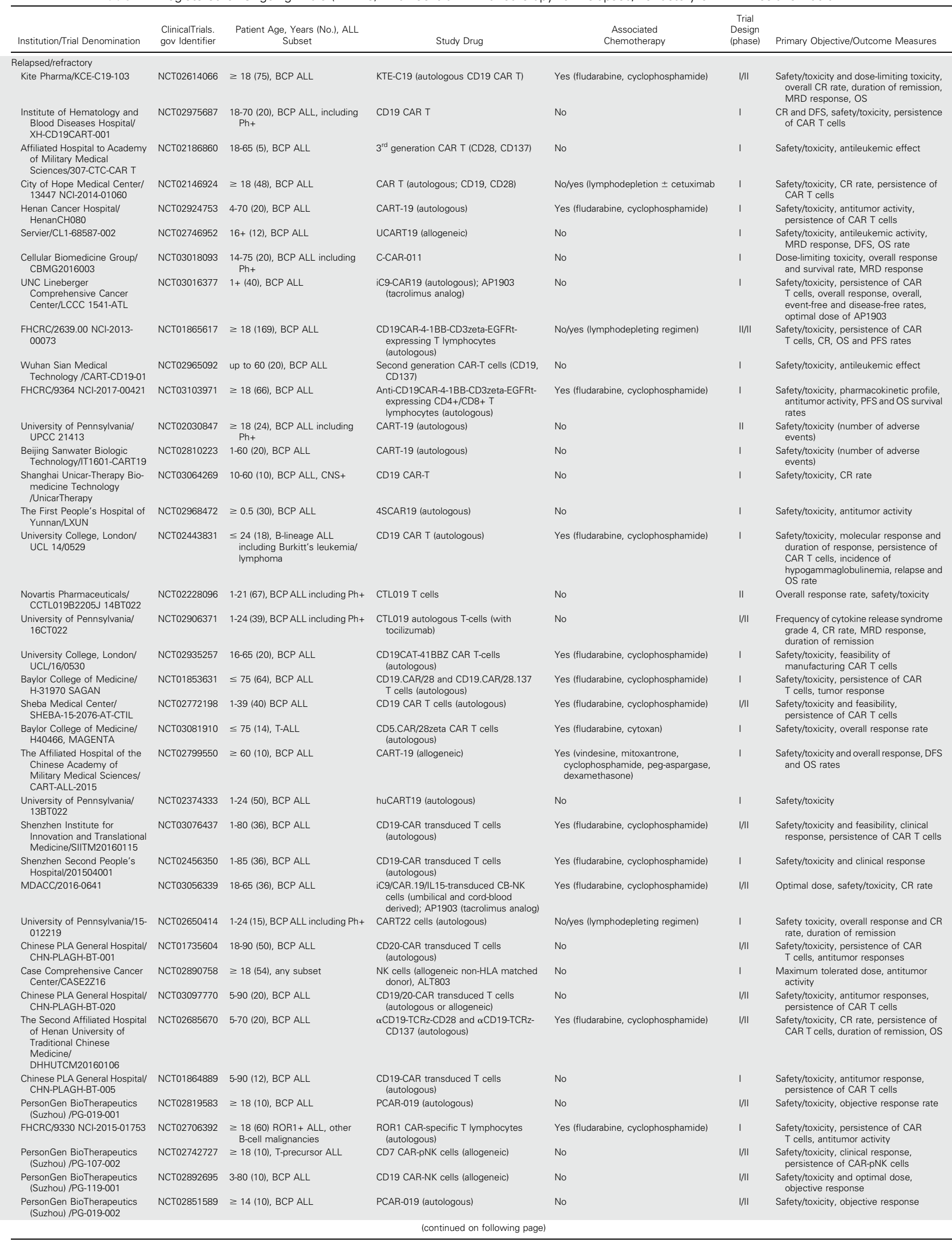




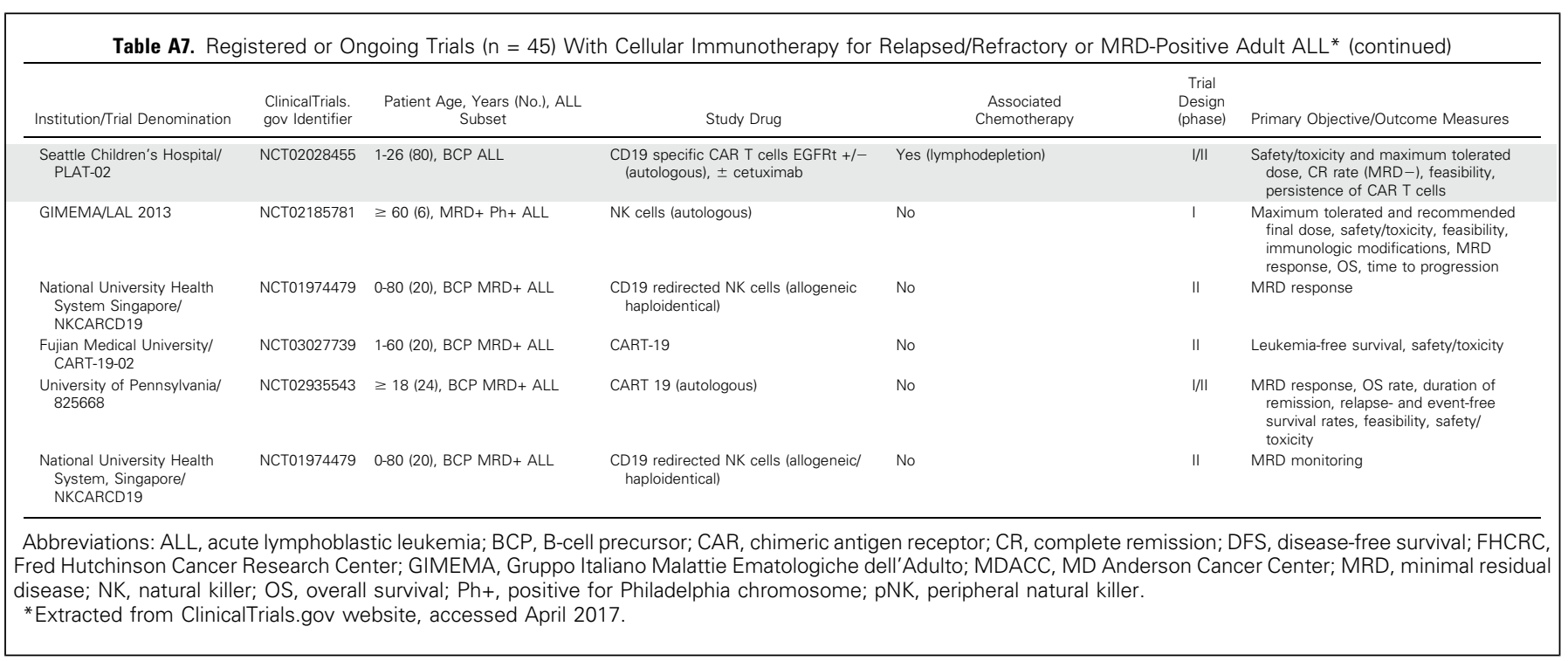

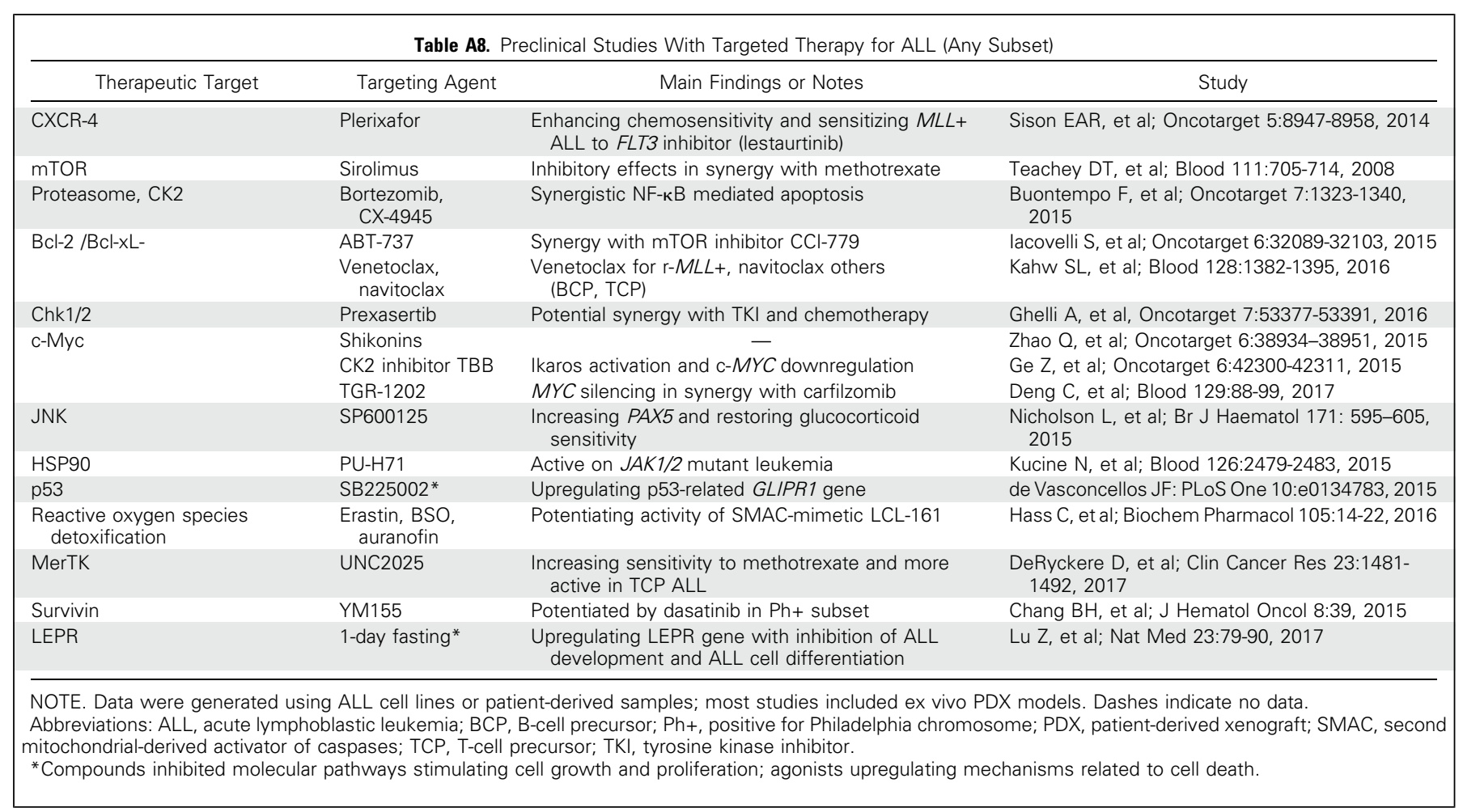


Table A9. Preclinical Studies With Targeted Therapy for BCP ALL and Subsets

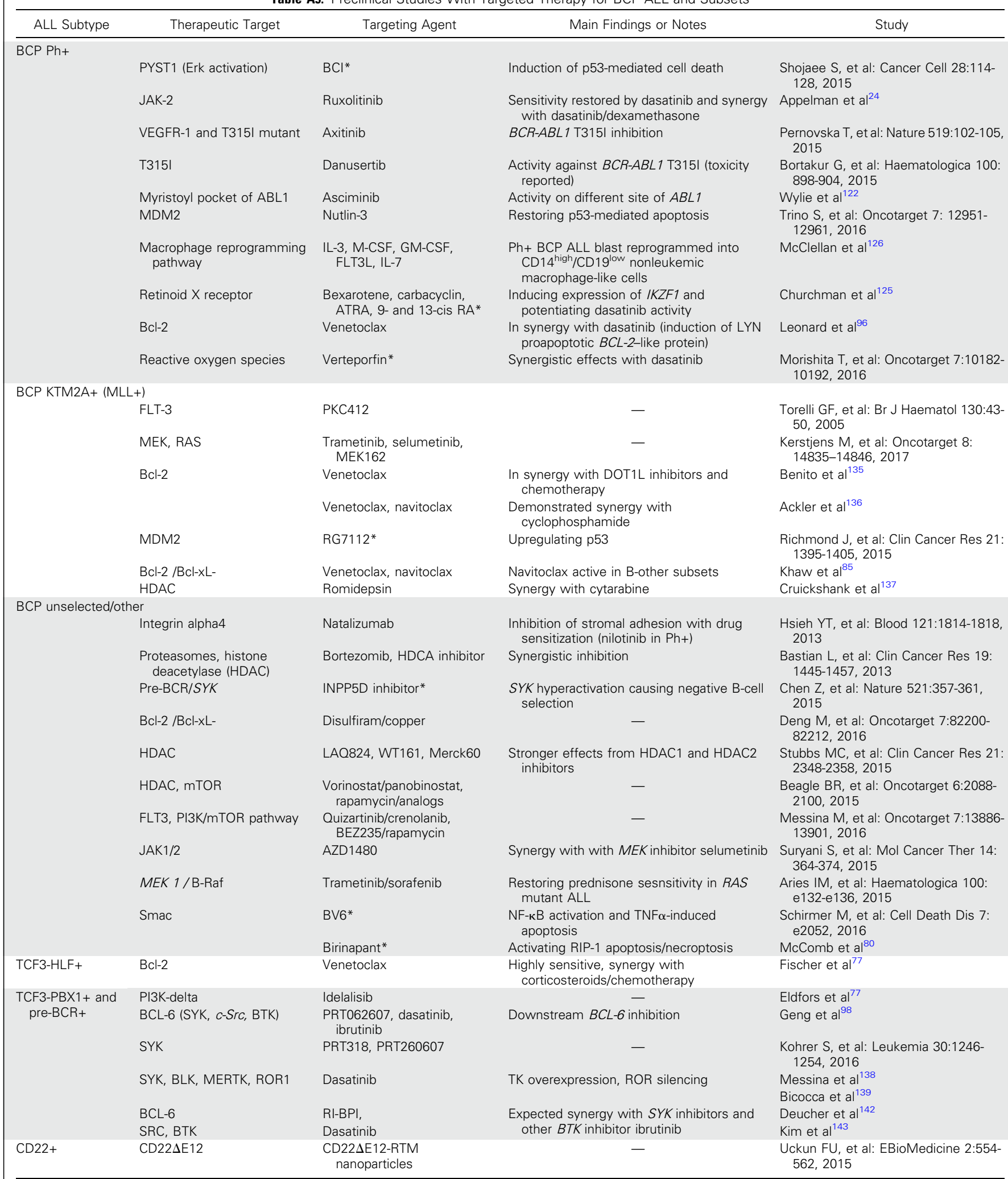

NOTE. Data were generated using ALL cell lines or patient-derived samples; most studies included ex vivo PDX models. Dashes indicate no data.

Abbreviations: ALL, acute lymphoblastic leukemia; BCP, B-cell precursor; HDCA, histone deacetylase; PDX, patient-derived xenograft; Ph+, positive for Philadelphia chromosome; TK, tyrosine kinase.

*Compounds inhibited molecular pathways stimulating cell growth and proliferation; agonists upregulating mechanisms related to cell death. 
Table A10. Preclinical Studies With Targeted Therapy for TCP ALL

\begin{tabular}{|c|c|c|c|c|}
\hline $\begin{array}{c}\text { ALL } \\
\text { Subtype }\end{array}$ & Therapeutic Target & Targeting Agent & Main Findings or Notes & Study \\
\hline \multicolumn{5}{|l|}{ TCP } \\
\hline & CD3 & $\begin{array}{l}\text { Anti-CD3/CD28 and CD3 } \varepsilon \\
\text { antibodies* }\end{array}$ & Triggering TCR signaling induces apoptosis & Trinquand et $\mathrm{al}^{160}$ \\
\hline & CD7 & CD7-nanobody toxin & Pseudomonas exotoxin A & $\begin{array}{l}\text { Tang J, et al: Oncotarget 7:34070-34083, } \\
2016\end{array}$ \\
\hline & CD38 & Daratumumab & Active in 14 of 15 pediatric T-ALL PDX models & Bride KL, et al: Blood 131:995-999, 2018 \\
\hline & \multirow[t]{2}{*}{$\mathrm{Bcl}-2$} & \multirow[t]{2}{*}{ Venetoclax } & $\begin{array}{l}\text { Synergy with chemotherapy; most active in } \\
T L X 3+\text { and } H O X A+\text { subsets }\end{array}$ & Peirs et $\mathrm{al}^{95}$ \\
\hline & & & $\begin{array}{l}\text { More effective in ETP ALL than other T-ALL } \\
\text { subsets }\end{array}$ & $\begin{array}{l}\text { Chongaile TN, et al: Cancer Discov 4:1074- } \\
\text { 1087, } 2014\end{array}$ \\
\hline & \multirow[t]{2}{*}{ IRAK-1/4 } & IRAK inhibitors & $\begin{array}{l}\text { Reducing MCL1 stability; synergy with ABT- } \\
737 \text { and vincristine }\end{array}$ & $\begin{array}{l}\text { Li Z, et al: J Clin Invest 125:1081-1097, } \\
2015\end{array}$ \\
\hline & & IRAK $1 / 4$ inhibitors & $\begin{array}{l}\text { Partial inhibition of proliferation and reversal } \\
\text { of corticosteroid resistance }\end{array}$ & $\begin{array}{l}\text { Dussiau C, et al: Oncotarget 6:18956- } \\
\text { 18965, } 2015\end{array}$ \\
\hline & NOTCH1-4 & 12 (BMS-906024) & Pan-NOTCH inhibitor & $\begin{array}{l}\text { Gavai AV, et al: ACS Med Chem Lett 6:523- } \\
\text { 527, } 2015\end{array}$ \\
\hline & NOTCH3 & MOR antibodies & Inhibiting NOTCH3 mutated T-ALL & $\begin{array}{l}\text { Bernasconi-Elias P, et al: Oncogene 35: } \\
\quad 6077-6086,2016\end{array}$ \\
\hline & Wnt & XAV-939 & $\begin{array}{l}\text { Targeting hypoxic, leukemia-initiating cell-rich } \\
\text { population }\end{array}$ & $\begin{array}{l}\text { Giambra V, et al: Blood 125:3917-3927, } \\
2015\end{array}$ \\
\hline & \multirow[t]{3}{*}{ CXCL-12/ CXCR-4 } & \multirow[t]{2}{*}{ CXCR4-inh AMD3465 } & $\begin{array}{l}\text { CXCL12 production by vascular endothelial } \\
\text { cells mantains T-ALL; CXCL12 and CXCR4 } \\
\text { genetic deletion suppresses T-ALL }\end{array}$ & Pitt et $\mathrm{al}^{161}$ \\
\hline & & & $\begin{array}{l}\text { CXCR4 critical to T leukemogenecity; } \\
\text { expression mediated by contactin and } \\
\text { calcineurin }\end{array}$ & Passaro et $a^{162}$ \\
\hline & & BMS-936564/MDX-1338 & Fully human anti-CXCR4 antibody & $\begin{array}{l}\text { Kuhne MR, et al: Clin Cancer Res 19:357- } \\
\text { 366, } 2012\end{array}$ \\
\hline & HDAC & Givinostat & - & $\begin{array}{l}\text { Pinazza M, et al: Cell Death Dis 7: e2047, } \\
2016\end{array}$ \\
\hline & Glutaminase & BPTES & $\begin{array}{l}\text { Inhibition of glutaminolysis and autophagy } \\
\text { in synergy with NOTCH inhibition by DBZ }\end{array}$ & $\begin{array}{l}\text { Herranz D, et al: Nat Med 21:1182-1189, } \\
2015\end{array}$ \\
\hline & Hedgehog & GANT61, vismodegib & T-ALL with high GLI1 expression & $\begin{array}{l}\text { Dagklis A, et al: Blood 128:2642-2654, } \\
2016\end{array}$ \\
\hline & HSP90 & AUY922 & Downregulating $T Y K 2$ and $B C L-2$ & $\begin{array}{l}\text { Akahane K, et al: Leukemia 30:219-228, } \\
2016\end{array}$ \\
\hline & $\mathrm{CK} 2$ & CX-4945 & $\begin{array}{l}\text { Inhibiting IL-7R mutant T-ALL, in synergy with } \\
\text { JAK inhibitors }\end{array}$ & $\begin{array}{l}\text { Melao A, et al: Hematologica 101:1368- } \\
\text { 1379, } 2016\end{array}$ \\
\hline & CDK4/6 & LEE011 & $\begin{array}{l}\text { Synergy with glucocorticoids and mTOR } \\
\text { inhibitor; antagonism with chemotherapy }\end{array}$ & $\begin{array}{l}\text { Pikman Y, et al: Clin Cancer Res 23:1012- } \\
\text { 1024, } 2016\end{array}$ \\
\hline & JAK/STAT pathway & Ruxolitinib & $\begin{array}{l}\text { Inhibition IL-7 associated STAT5 } \\
\text { hyperactivation in ETP ALL }\end{array}$ & Maude et al $^{166}$ \\
\hline & TYK2 & JAK inhibitor 1, AG490 & - & $\begin{array}{l}\text { Sanda T, et al: Cancer Discov 3:564-577, } \\
2013\end{array}$ \\
\hline & $\begin{array}{l}\text { NEDD8-activating enzyme } \\
\text { E1C }\end{array}$ & MLN4924 & - & $\begin{array}{l}\text { Han K, et al: Oncotarget 7:23812-23824, } \\
2016\end{array}$ \\
\hline & $\begin{array}{l}\mathrm{PI} \text { IK/mTOR AKT/mTOR, } \\
\text { c-Myc }\end{array}$ & $\begin{array}{l}\text { Rapamycin, JQ1 (bromodomain } \\
\text { inhibitor) }\end{array}$ & Targeting leukemia-initiating cells & $\begin{array}{l}\text { Schubbert S, et al: Cancer Res 74:7048- } \\
\text { 7059, } 2014\end{array}$ \\
\hline & PI3K/mTOR AKT/mTOR, & IPI-145 (pan PI3K inhibitor) & $\begin{array}{l}\text { More efficient than isoform-selective PI3K } \\
\text { inhibitors }\end{array}$ & $\begin{array}{l}\text { Lonetti A, et al: Oncotarget 6:10399- } \\
10414,2016\end{array}$ \\
\hline & & $\begin{array}{l}\text { AZD8835/8186, AZD5363, } \\
\text { AZD2014 }\end{array}$ & Identification of sensitive T-ALL subsets & $\begin{array}{l}\text { Lynch JT, et al: Oncotarget 7:22128-22139, } \\
2016\end{array}$ \\
\hline & & AS605240 & $\begin{array}{l}\text { Synergistic with glucococorticoids; } \\
\text { antagonistic interaction with anthracycline } \\
\text { and methotrexate unless administered } \\
\text { after } 48 \text { hours }\end{array}$ & $\begin{array}{l}\text { Bortolini Silveira A, et al: Oncotarget 6: } \\
\text { 13105-13118, } 2015\end{array}$ \\
\hline & hLAT1 & JPH2013 & - & $\begin{array}{l}\text { Rosilio C, et al: Leukemia 29:1253-1266, } \\
2015\end{array}$ \\
\hline & $\begin{array}{l}\text { Calcineurin (Cn)-nuclear } \\
\text { factor/GSK-3 }\end{array}$ & $\mathrm{Cn} / G S K-3$ inhibitors & $\begin{array}{l}\text { Dual inhibition increasing proteosomal } \\
\text { degradation of X-linked inhibitor of } \\
\text { apoptosis (in pre-/pro-T ALL) }\end{array}$ & $\begin{array}{l}\text { Tosello V, et al: Leukemia 30:812-822, } \\
2016\end{array}$ \\
\hline & Src TK $L C K$ & Dasatinib & Activity in TAL1/SIL-TAL1 subset & $\begin{array}{l}\text { Laukkanen S, et al: Blood Cancer J 7:e604, } \\
2017\end{array}$ \\
\hline & LCK & $\begin{array}{l}\text { Dasatinib, bosutinib, } \\
\text { nintedanib, WH-4-023 }\end{array}$ & $\begin{array}{l}\text { Restoring sensitivity to dexamethasone in } \\
\text { glucocorticoid-resistant leukemic cells }\end{array}$ & Serafin V, et al: Blood 130:2750-2751, 2017 \\
\hline
\end{tabular}

NOTE. Data were generated using ALL cell lines or patient-derived samples; most studies included ex vivo PDX models. Dashes indicate no data.

Abbreviations: ALL, acute lymphoblastic leukemia; ETP, early thymic precursor; PDX, patient-derived xenograft; TCP, T-cell precursor; TCR, T-cell receptor.

${ }^{*}$ Compounds inhibited molecular pathways stimulating cell growth and proliferation; agonists upregulating mechanisms related to cell death. 